\title{
Lasmiditan and 5-Hydroxytryptamine in the rat trigeminal system; expression, release and interactions with $5-\mathrm{HT}_{1}$ receptors
}

Jacob C. A. Edvinsson ${ }^{1,2^{*}}$, Aida Maddahi ${ }^{3}$, Isabella M. Christiansen ${ }^{1,4}$, Philip V. Reducha ${ }^{1,4}$, Karin Warfvinge ${ }^{1,3}$, Majid Sheykhzade ${ }^{2}$, Lars Edvinsson ${ }^{1,3}$ and Kristian A. Haanes ${ }^{1,4}$

\begin{abstract}
Background: 5-Hydroxytryptamine (5-HT) receptors 1B, 1D and 1F have key roles in migraine pharmacotherapy. Selective agonists targeting these receptors, such as triptans and ditans, are effective in aborting acute migraine attacks and inhibit the in vivo release of calcitonin gene-related peptide (CGRP) in human and animal models. The study aimed to examine the localization, genetic expression and functional aspects of $5-H_{1 B / 1 D / 1 F}$ receptors in the trigeminal system in order to further understand the molecular sites of action of triptans $\left(5-\mathrm{HT}_{1 \mathrm{~B} / 1 \mathrm{D}}\right)$ and ditans $\left(5-\mathrm{HT}_{1 \mathrm{~F}}\right)$.
\end{abstract}

Methods: Utilizing immunohistochemistry, the localization of 5-HT and of 5-HT $1 \mathrm{~B} / 1 \mathrm{D} / 1 \mathrm{~F}$ receptors was examined in rat trigeminal ganglion (TG) and combined with quantitative polymerase chain reaction to quantify the level of expression for $5-\mathrm{HT}_{1 \mathrm{~B} / 1 \mathrm{D} / 1 \mathrm{~F}}$ receptors in the $\mathrm{TG}$. The functional role of these receptors was examined ex vivo with a capsaicin/ potassium induced 5-HT and CGRP release.

Results: 5 -HT immunoreactivity (ir) was observed in a minority of CGRP negative C-fibres, most neuron somas and faintly in A-fibres and Schwann cell neurolemma. $5-\mathrm{HT}_{1 \mathrm{~B} / 1 \mathrm{D}}$ receptors were expressed in the $\mathrm{TG}$, while the $5-\mathrm{HT}_{1 \mathrm{~F}}$ receptor displayed a weak ir. The $5-\mathrm{HT}_{1 \mathrm{D}}$ receptor co-localized with receptor activity-modifying protein 1 (RAMP1) in A $\delta$-fibres in the TG, while 5- $\mathrm{HT}_{1 \mathrm{~B}}$-ir was weakly expressed and 5- $\mathrm{HT}_{1 \mathrm{~F}}$-ir was not detected in these fibres. None of the 5-HT, receptors co-localized with CGRP-ir in C-fibres.

$5-\mathrm{HT}_{1 \mathrm{D}}$ receptor mRNA was the most prominently expressed, followed by the $5-\mathrm{HT}_{1 \mathrm{~B}}$ receptor and lastly the $5-\mathrm{HT}_{1 \mathrm{~F}}$ receptor. The 5-HT $1 \mathrm{~B}$ and 5-HT 1 receptor antagonist, GR127935, could reverse the inhibitory effect of Lasmiditan (a selective 5-HT 1 receptor agonist) on CGRP release in the soma-rich TG but not in soma-poor TG or dura mater. 5-HT release in the soma-rich TG, and 5-HT content in the baseline samples, negatively correlated with CGRP levels, showing for the first time a physiological role for 5-HT induced inhibition.

Conclusion: This study reveals the presence of a subgroup of $\mathrm{C}$-fibres that store $5-\mathrm{HT}$. The data shows high expression of $5-\mathrm{HT}_{1 \mathrm{~B} / 1 \mathrm{D}}$ receptors and suggests that the $5-\mathrm{HT}_{1 \mathrm{~F}}$ receptor is a relatively unlikely target in the rat $\mathrm{TG}$. Furthermore, Lasmiditan works as a partial agonist on $5-\mathrm{HT}_{1 \mathrm{~B} / 1 \mathrm{D}}$ receptors in clinically relevant dose regiments.

Keywords: 5-HT, Lasmiditan, CGRP, Migraine, Trigeminal system

*Correspondence: jacob.edvinsson@sund.ku.dk

2 Department of Drug Design and Pharmacology, Faculty of Health and Medical Sciences, University of Copenhagen, Copenhagen, Denmark

Full list of author information is available at the end of the article

\section{Introduction}

Migraine headache has historically been considered a vascular disorder where vasodilatation of cranial (extracerebral) blood vessels generates activation of trigeminal original author(s) and the source, provide a link to the Creative Commons licence, and indicate if changes were made. The images or other third party material in this article are included in the article's Creative Commons licence, unless indicated otherwise in a credit line to the material. If material is not included in the article's Creative Commons licence and your intended use is not permitted by statutory regulation or exceeds the permitted use, you will need to obtain permission directly from the copyright holder. To view a copy of this licence, visit http://creativecommons.org/licenses/by/4.0/. The Creative Commons Public Domain Dedication waiver (http://creativeco mmons.org/publicdomain/zero/1.0/) applies to the data made available in this article, unless otherwise stated in a credit line to the data. 
afferents which is associated with pain [1]. This view has over time been challenged by the hypothesis that favour a neurological origin [2]. The generation of a migraine attack has been proposed to be initiated in the central nervous system (CNS), involving regions such as the hypothalamus and brainstem, much of this is associated with the premonitory symptoms found in many patients [3]. In support, neuroimaging studies on migraineurs with daily scanning over 30 days have revealed hypothalamic activation in the premonitory phase and increased activity in the ictal phase for brainstem regions (e.g. pontine tegmentum) $[4,5]$.

Although the origin of migraine may be in the CNS, the perceived pain is referred through the trigeminovascular system (TVS), which includes the trigeminal ganglion (TG), and bridge the trigeminocervical complex with the brain [6]. Due to the low blood-brain barrier (BBB) permeability and clinically proven effectiveness of triptans and calcitonin gene-related peptide (CGRP) monoclonal antibodies, the TG and its afferents are a likely target in migraine pharmacotherapy.

Triptans are clinically well established and effective drugs indicated for the treatment of acute migraine headache attacks [7]. The available triptans are functionally homogenous in their mode of action with differences to be found in bioavailability and pharmacokinetics (e.g. half-life) $[8,9]$. These drugs were originally developed on the assumption that reduced vasodilatation would alleviate migraine headache, however, we now know that $5-\mathrm{HT}_{1}$ receptor agonists (e.g. sumatriptan) can substantially inhibit release of neuropeptides such as CGRP and Substance P $(\mathrm{SP})[10,11]$, thus revealing a potential mechanism of action relevant to migraine therapy [12].

Triptans are 5-hydroxytryptamine (5-HT) receptor agonists with high affinity for the $5-\mathrm{HT}_{1 \mathrm{~B} / 1 \mathrm{D}}$ receptor subtypes and with moderate affinity for $5-\mathrm{HT}_{1 \mathrm{~A}}$ and $5-\mathrm{HT}_{1 \mathrm{~F}}$ receptors [13, 14]. They elicit potent vasoconstrictive effects in cranial arteries mainly via the $5-\mathrm{HT}_{1 \mathrm{~B}}$ receptor. The $5-\mathrm{HT}_{1 \mathrm{~B}}$ receptor is expressed on smooth muscle cells in cerebral [15], meningeal [16] and coronary arteries [17]. While the 5- $\mathrm{HT}_{1 \mathrm{D}}$ receptor is less effective in inducing vasoconstriction [18], it is prominently expressed in the TG $[19,20]$. A $5-\mathrm{HT}_{1 \mathrm{D}}$ agonist was found to block both peripheral and central aspects of TVS activation [21]. Lasmiditan, a recently developed selective $5-\mathrm{HT}_{1 \mathrm{~F}}$ receptor agonist [22], does not induce vasoconstriction but has both a CGRP release inhibiting potential and an anti-migraine effect [23-25].

Pharmacological studies have suggested that $5-\mathrm{HT}_{1 \mathrm{D}}$ receptor agonists should inhibit trigeminal nociceptive traffic though less potently than via the $5-\mathrm{HT}_{1 \mathrm{~B}}$ receptor [26]. The same study concluded that blocking the $5-\mathrm{HT}_{1 \mathrm{D}}$ receptor with the selective antagonist BRL-15572 reduced the inhibitory effect of several triptans, thus showing that $5-\mathrm{HT}_{1 \mathrm{D}}$ receptors may yet have a role to play in migraine pharmacotherapy. It should be noted that the only attempted clinical trial with a specific $5-\mathrm{HT}_{1 \mathrm{D}}$ receptor agonist (PNU-142633) proved ineffective in aborting migraine attacks [27]. However, the results of the study has been deemed inconclusive [14] in part due to low sample size and uncertain receptor affinity [28].

While 5-HT is broadly reported to be expressed in mast cells and platelets, the inconclusive expression of 5- $\mathrm{HT}$ in nerve fibres innervating cerebral arteries have been suggested to be attributed to extracellular uptake [29]. Tryptophan hydroxylase (TPH), the rate-limiting enzyme in the 5 -HT biosynthesis, immunoreactivity (ir) has been found in both thin varicose nerve fibres (likely $\mathrm{C}$-fibres) and thicker nerve bundles (likely A $\delta$-fibres) inhabiting the rat dura mater [29]. However, the presence of TPH was not deemed sufficient in synthesizing measurable amounts of 5-HT in these fibres, making it an uncertain marker for "authentic" serotonergic innervation [29]. A previous study, utilizing real-time polymerase chain reaction, also faced technical difficulties in measuring TPH mRNA levels in central serotonergic neurons due to its low levels [30].

The aim of this study was to revisit the field of $5-\mathrm{HT}_{1}$ receptor subtypes to shed light on their probable site of action within the trigeminal nerve. In addition, we wanted to study the expression of their natural ligand, 5-HT, within this region. To achieve this, we applied immunohistochemistry (IHC) to obtain a detailed visualization of 5-HT and its relevant receptors. The expression of $5-\mathrm{HT}_{1}$ receptor subtypes was compared utilizing quantitative polymerase chain reaction (qPCR) and a light emission measurement. Lastly, functional aspects of CGRP and 5-HT release were explored in ex vivo TG and a hemi-skull model.

\section{Materials \& methods Animals}

All animal procedures were performed in accordance with the European Community Council Directive on 'The Protection of Animals Used for Scientific Purposes' (2010/63/EU). Animal procedures were approved by the Lund University Animal Ethics Committee (M43-07) and The Danish Animal Experimentation Inspectorate respectively.

Adult male Sprague Dawley rats (260-300 g), housed in groups of 2-3 rats together in Tall IVC Rat Cages (Innovive), were utilized for the IHC part of this study. For CGRP and 5-HT release experiments additional Sprague Dawley rats (260-300 g) were used. These rats were housed in Eurostandard cages (Type VI with 123-Lid) in groups of 2-6 rats together. 
All animals were kept under standard laboratory conditions (humidity-controlled, and 12/12h light-dark cycle, with dark beginning at 7 p.m.) with access to chow (RM1, SDS) and water ad libitum. All animals were first anaesthetized by $\mathrm{CO}_{2}$ inhalation and subsequently decapitated prior to experiments.

\section{RNA isolation and qPCR}

TGs from 8 male rats were carefully dissected and immediately frozen on liquid nitrogen for RNA extraction. RNA was extracted from all samples using RNeasy ${ }^{\circledR}$ Plus Mini kit (Qiagen, Hilden, Germany) in accordance to the manufacturer's protocol. Total RNA concentration was determined using a GeneQuant Pro spectrophotometer (Amersham Pharmacia Biotech, Uppsala, Sweden). A ratio of sample absorbance at $260 / 280 \mathrm{~nm}$ in the range of 1.8 to 2.0 was deemed acceptable. $1 \mu \mathrm{g}$ total RNA was used in a $20 \mu \mathrm{L}$ reverse transcript reaction using SuperScript $^{\circledR}$ III First-Strand Synthesis Super Mix (Invitrogen, Carlsbad, CA, USA) for qPCR. In order to detect genomic DNA, a reverse transcription negative control was performed simultaneously for each sample, but in the absence of SuperScript III Reverse Transcriptase, for each sample to detect genomic DNA. The obtained cDNA was diluted to a total volume of $80 \mu \mathrm{L}$ and stored frozen at $-20{ }^{\circ} \mathrm{C}$. Primer sequences (for details, see Table 1) were specific for the genes of interest and were designed using Primer Express 3.0 software (PE Applied Biosystems, Foster city, CA, USA) and synthesized by TAG Copenhagen A/S (Copenhagen, Denmark). Glyceraldehyde-3-phosphate dehydrogenase (GAPDH) was utilized as a housekeeping gene to which the gene expressions were normalized against.

The qPCR was performed in $20 \mu \mathrm{L}$ total volume reaction consisting of $2 \mu \mathrm{L}$ diluted cDNA, $0.5 \mu \mathrm{M}$ of each primer, and $10 \mu \mathrm{L}$ Fast $\mathrm{SYBR}^{\mathrm{TM}}$ Green Master Mix (Applied Biosystems, CA, USA), and $7 \mu \mathrm{L}$ RNAase free water in a Step One Plus Real Time PCR System (Applied Biosystems, CA, USA). The qPCR reaction had the following thermal profile: Holding stage at $+50{ }^{\circ} \mathrm{C}$ for $2 \mathrm{~min}$ and $+95^{\circ} \mathrm{C}$ for $10 \mathrm{~min}$, followed by 40 PCR cycles at +95 ${ }^{\circ} \mathrm{C}$ for $15 \mathrm{~s}$ and $+60{ }^{\circ} \mathrm{C}$ for $1 \mathrm{~min}$. Each sample was examined in duplicate and a blank control (without template) was used in all experiments. After amplification a melting curve analysis was performed to verify that each primer pair generated only one PCR product of expected size.

\section{Immunohistochemistry}

TGs were carefully dissected and incubated in $4 \%$ paraformaldehyde in phosphate buffered saline (PBS) for 2-4 $\mathrm{h}$ at room temperature. The fixated TGs were immersed in $10 \%$ sucrose (Sigma) in Sorensen's phosphate buffer $\left(2-4 \mathrm{~h},+4{ }^{\circ} \mathrm{C}\right)$ and subsequently in a $25 \%$ solution overnight. The following day, the TGs were embedded in a gelatine medium ( $30 \%$ egg albumin, $3 \%$ gelatine) and cryosectioned at $10 \mu \mathrm{m}$. The sections were mounted on microscope slides (Superfrost, ThermoFisher) and stored at $-20{ }^{\circ} \mathrm{C}$ until use.

The TG sections were rehydrated and permeabilized in $0.25 \%$ Triton X-100 diluted in PBS (PBS-T; Sigma) for $2 \times 15$ minutes. Primary antibodies (for details, see Table 2) diluted in PBS-T containing $1 \%$ bovine serum albumin (BSA; Sigma) were applied to the sections which were incubated at $+4{ }^{\circ} \mathrm{C}$ overnight. Sections were subsequently rinsed of excess antibodies in PBS-T for $2 \times 15$ min and incubated with secondary antibodies (for details, see Table 2), diluted in PBS-T, for $1 \mathrm{~h}$ in a dark room. Afterwards, excess secondary antibodies were rinsed with PBS-T $2 \times 15$ min and cover glass was mounted with anti-fading medium Vectashield containing 4,6-diamidino-2-phenylindole (DAPI; Vector Laboratories, Burlingame CA, USA). For double immunohistochemical stainings, the process was repeated on the same sample with an additional primary and secondary antibody. Negative controls were simultaneously made following the same procedure but in the absence of primary antibodies. The mounted sections were examined with an epifluorescence microscope (Nikon 80i, Tokyo, Japan) coupled to a Nikon DS-2 MV camera. Images were obtained with NIS basic research software (Nikon, Japan) and processed into figures using Adobe Photoshop CC 2020 (Adobe Systems, Mountain View, CA, USA).

\section{Light intensity measurements}

The level of ir was compared between $5-\mathrm{HT}_{1 \mathrm{~B} / \mathrm{D} / \mathrm{F}}$ receptors using microphotographs from IHC results. To reduce bias and confounding factors, all measured areas were compared (Fig. 5) and measurements were only

Table 1 Details of qPCR primer sequences

\begin{tabular}{|c|c|c|}
\hline Primer & Forward & Reverse \\
\hline $5-\mathrm{HT}_{1 \mathrm{~B}}$ & 5’-TCCGGGTCTCCTGTGTACGT -3’ & $5^{\prime}$-GGCGTCTGAGACTCGCACTT -3` \\
\hline $5-\mathrm{HT}_{1 \mathrm{D}}$ & 5`-GCATCTCTGTGTCATCGCTCT -3’ & $5^{\prime}$-ATGTGTTCACCAGGCAGTCA -3' \\
\hline $5-\mathrm{HT}_{1 \mathrm{~F}}$ & 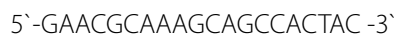 & $5^{\prime}$-AGGTAACCAAGCCATGCCAA -3` \\
\hline GAPDH & $5^{\prime}-\mathrm{CTGCACCACCAACTGCTTAGG}-3^{\prime}$ & 5'-TCAGCTCTGGGATGACCTTGC- 3 \\
\hline
\end{tabular}


Table 2 Details of primary and secondary antibodies

\begin{tabular}{|c|c|c|c|c|}
\hline \multicolumn{5}{|c|}{ Primary antibodies } \\
\hline Antigen & Dilution & Species & Immunogen & Supplier \\
\hline CGRP (ab81887) & $1 ; 100$ & Mouse & Rat alpha-CGRP & Abcam, Cambridge, UK \\
\hline $5-\mathrm{HT}_{1 \mathrm{~B}}(\mathrm{ab} 13896)$ & $1 ; 100$ & Rabbit & Amino acids 8-26 and 263-278 of 5- HT1B & Abcam, Cambridge, UK \\
\hline $5-\mathrm{HT}_{1 \mathrm{D}}(\mathrm{ab} 13895)$ & $1 ; 100$ & Rabbit & Amino acids $1-18$ and $251-267$ of rat 5-HT1D & Abcam, Cambridge, UK \\
\hline $5-\mathrm{HT}_{1 \mathrm{~F}}(\mathrm{SP} 4043 \mathrm{P})$ & $1 ; 100$ & Rabbit & N-terminus extracellular domain of human 5-HT1F & Acris Antibodies, San Diego, CA, USA \\
\hline $5-\mathrm{HT}(20079)$ & $1 ; 100$ & Goat & $\begin{array}{l}\text { Serotonin whole molecule conjugated to BSA with para- } \\
\text { formaldehyde. }\end{array}$ & Immunostar, Hudson, WI, USA \\
\hline $5-\mathrm{HT}_{1 \mathrm{~F}}(\mathrm{TA340657)}$ & $1 ; 100$ & Rabbit & $\begin{array}{l}5-H T_{1 F} \text { Receptor antibody was raised against synthetic } 19 \\
\text { amino acid peptide from } \mathrm{N} \text {-terminal extracellular domain of } \\
\text { human } 5 \mathrm{HT}_{1 \mathrm{~F}} \text { Receptor }\end{array}$ & Origene, Rockville, MD, USA \\
\hline CASPR (MABN69) & $1 ; 100$ & Mouse & $\begin{array}{l}\text { Recombinant protein corresponding to rat contactin associ- } \\
\text { ated protein } 1 .\end{array}$ & EMD milipore Corp. Temecula, CA, USA \\
\hline RAMP1 (844) & $1 ; 200$ & Goat & C-terminal of human RAMP1 & Merck \& Co, Inc., West Point, PA, USA. \\
\hline MBP (MA5-15922) & $1 ; 100$ & Mouse & $\begin{array}{l}\text { Purified recombinant fragment of human MBP expressed in } \\
\text { E.Coli. }\end{array}$ & Thermo Fisher Scientific, Waltham, MA, USA. \\
\hline \multicolumn{5}{|c|}{ Secondary antibodies } \\
\hline Product & Dilution & Immunogen & Supplier & \\
\hline FITC & $1 ; 100$ & Anti-rabbit & Cayman Chemical, Ann Arbor, MI, USA & \\
\hline Alexa flour 594 & $1 ; 100$ & Anti-mouse & \multicolumn{2}{|l|}{ Jackson Immunoresearch Laboratories, Inc., West Grove, PA, USA } \\
\hline Dyelight 488 & $1 ; 100$ & Anti-rabbit & \multicolumn{2}{|l|}{ Jackson Immunoresearch Laboratories, Inc., West Grove, PA, USA } \\
\hline Cy3 & $1 ; 200$ & Anti-goat & \multicolumn{2}{|l|}{ Jackson Immunoresearch Laboratories, Inc., West Grove, PA, USA } \\
\hline FITC & $1 ; 100$ & Anti-mouse & \multicolumn{2}{|l|}{ Jackson Immunoresearch Laboratories, Inc., West Grove, PA, USA } \\
\hline
\end{tabular}

made for primary antibodies from the same species (rabbit) utilizing the same secondary antibody.

For 5 - $\mathrm{HT}_{1}$ receptors, each TG was microphotographed (18 per antibody, $n=6$ ). All microphotographs were taken in greyscale at $333 \mathrm{~ms}$ exposure in the FITC filter and each primary antibody (all rabbit, 1:100) had been labelled with the same secondary antibody (FITC, antirabbit, 1:100).

All microphotographs were taken in areas of $0.09375 \mathrm{~mm}^{2}$ containing at least 10 visible neurons. The images were converted to greyscale, neurons were outlined using a freehand tool in the ImageJ software [31]. All light emission measurements were performed in ImageJ and the data was processed in GraphPad Prism 8.0.

\section{CGRP and 5-HT release}

Each TG was carefully dissected and transferred to an Eppendorf tube containing $1 \mathrm{~mL}$ synthetic interstitial fluid (SIF, composition: $108 \mathrm{mM} \mathrm{NaCl}, 3.5 \mathrm{mM} \mathrm{KCl}, 3.5$ $\mathrm{mM} \mathrm{MgSO}$, $26 \mathrm{mM} \mathrm{NaHCO}, 11.7 \mathrm{mM} \mathrm{NaH}_{2} \mathrm{PO}_{4}, 1.5$ $\mathrm{mM} \mathrm{CaCl}$, $9.6 \mathrm{mM}$ Sodium Gluconate, $5.6 \mathrm{mM}$ glucose and $7.6 \mathrm{mM}$ sucrose; $\mathrm{pH}$ 7.4.) which was incubated at $+37^{\circ} \mathrm{C}$ for $30 \mathrm{~min}$.

To reduce the baseline signals, the tissues were washed five consecutive times in $300 \mu \mathrm{L}$ SIF at $+37^{\circ} \mathrm{C}$ for $10 \mathrm{~min}$. Subsequently, $200 \mu \mathrm{L}$ samples from each tube was collected to assess a baseline for each tissue. CGRP and 5-HT release was induced by immersion in $60 \mathrm{mM} \mathrm{K}^{+}$-SIF, where an equimolar amount of $\mathrm{Na}^{+}$ was replaced by $\mathrm{K}^{+}$to maintain osmolality or $100 \mathrm{nM}$ capsaicin, for 10 minutes after which $200 \mu \mathrm{L}$ samples were collected. $50 \mu \mathrm{L}$ enzyme immunoassay buffer was added to each sample which was then stored frozen at $-20^{\circ} \mathrm{C}$ until analysis. For the experiments with agonist/ antagonists, the experiments were performed sequentially, with pre-incubation for 10 minutes for each [32]. For Lasmiditan (ACHEMblock, L22337, USA) a $30 \mathrm{mM}$ stock in dimethyl sulfoxide (DMSO) was prepared, GR127935 (Tocris, UK) was dissolved in water and kept frozen as stocks of $3 \mathrm{mM}$. BRL15572 (Tocris, UK) was dissolved in DMSO and kept frozen as stocks of $1.25 \mathrm{mM}$. All experiments were performed with matching vehicles.

The samples were processed using commercial enzyme immunoassay kits, Human CGRP enzymelinked immunosorbent assay (ELISA) KIT (SPIbio, Paris, France) for CGRP and Serotonin ELISA kit, (Enzo Life sciences, ADI-900-175, detection limit 0.293 $\mathrm{ng} / \mathrm{ml}$ ). The protocol was performed according to the manufacturer's instructions and the optical density was measured at $410 \mathrm{~nm}$ for both using a micro-plate photometer (Tecan, Infinite M200, software SW Magellan v.6.3, Männedorf, Switzerland). 


\section{Statistics}

Quantitative data obtained from release experiments was analysed using GraphPad Prism 8.0, and presented as mean \pm SEM. The differences between the variables were compared with a two-sided paired Student's t-test if the data passed the Shapiro-Wilks test for normality. For the correlation, the data is presented as individual points with $\mathrm{p}$-values and the $\mathrm{R}^{2}$-value was obtained from the correlation analysis in GraphPad 8.0.

Data from the real time PCR was analysed with the comparative cycle threshold $\left(C_{t}\right)$ method [33]. The $C_{t}$ values for $\mathrm{GAPDH}, 5-\mathrm{HT}_{1 \mathrm{~B}}, 5-\mathrm{HT}_{1 \mathrm{D}}$ and $5-\mathrm{HT}_{1 \mathrm{~F}} \mathrm{mRNA}$ were used as a reference to quantify the relative amount of mRNA. The relative amount of mRNA was calculated using the formula $X_{0} / R_{0}=2^{(\text {CtR-CtX) }}$. Where $X_{0}$ is the amount of target mRNA, $R_{0}$ is the amount of housekeeping gene mRNA, $C_{t} R$ is the $C_{t}$ value of the housekeeping gene and $C_{t} X$ is the $C_{t}$ value of the target. Data is expressed as mean $\pm S E M$ and $n$ refers to the number of rats. Statistical analyses for the real time PCR and the light emission measurement were performed with Kruskal Wallis non-parametric test with Dunn's posthoc test, using GraphPad Prism 8. ${ }^{*} P<0.05$, ${ }^{* *} P<0.01$ and $* * P<0.001$ were considered significant.

\section{Results}

5-HT, receptor light emission measurements

Light emission measurements of IHC stained TG neurons demonstrated that $5-\mathrm{HT}_{1 \mathrm{~F}}(23.6 \pm 4.2 \mathrm{AU}, \mathrm{n}=6)$ was too weakly expressed in the trigeminal neuron cell bodies to significantly differentiate from the negative control (19.1 $\pm 7.2 \mathrm{AU}, n=6$; $p<0.05)$ (Fig. 1A). In addition, measurements for $5-\mathrm{HT}_{1 \mathrm{~B}}(76.4 \pm 11.1 \mathrm{AU}, n=6)$ and $5-\mathrm{HT}_{1 \mathrm{D}}(52.8 \pm 11.6 \mathrm{AU}, n=6)$ receptors significantly differentiated from the negative control $(p>0.05)$ but not from each other (n.s). No significant difference in the measured areas was detected (Fig. 1B).

\section{Immunohistochemistry}

5-HT-ir was found in the cytoplasm of all observed neuronal cell bodies where it co-localized with $5-\mathrm{HT}_{1 \mathrm{~B} / 1 \mathrm{D} / 1 \mathrm{~F}}$ receptor ir (Fig. 2A-C). The 5-HT-ir was displayed in a granular pattern which often concentrated close to the cell membrane. 5-HT-ir was sporadically and faintly expressed in Schwann cells and satellite glial cells (SGCs). In addition, 5-HT-ir could be unevenly observed in A $\delta$-fibres and Schwann cell neurolemma but did not colocalize with myelin basic protein (MBP) (Fig. 3).

When double stained with CGRP and SP, 5-HT-ir could be detected in CGRP or SP positive neuron cell bodies

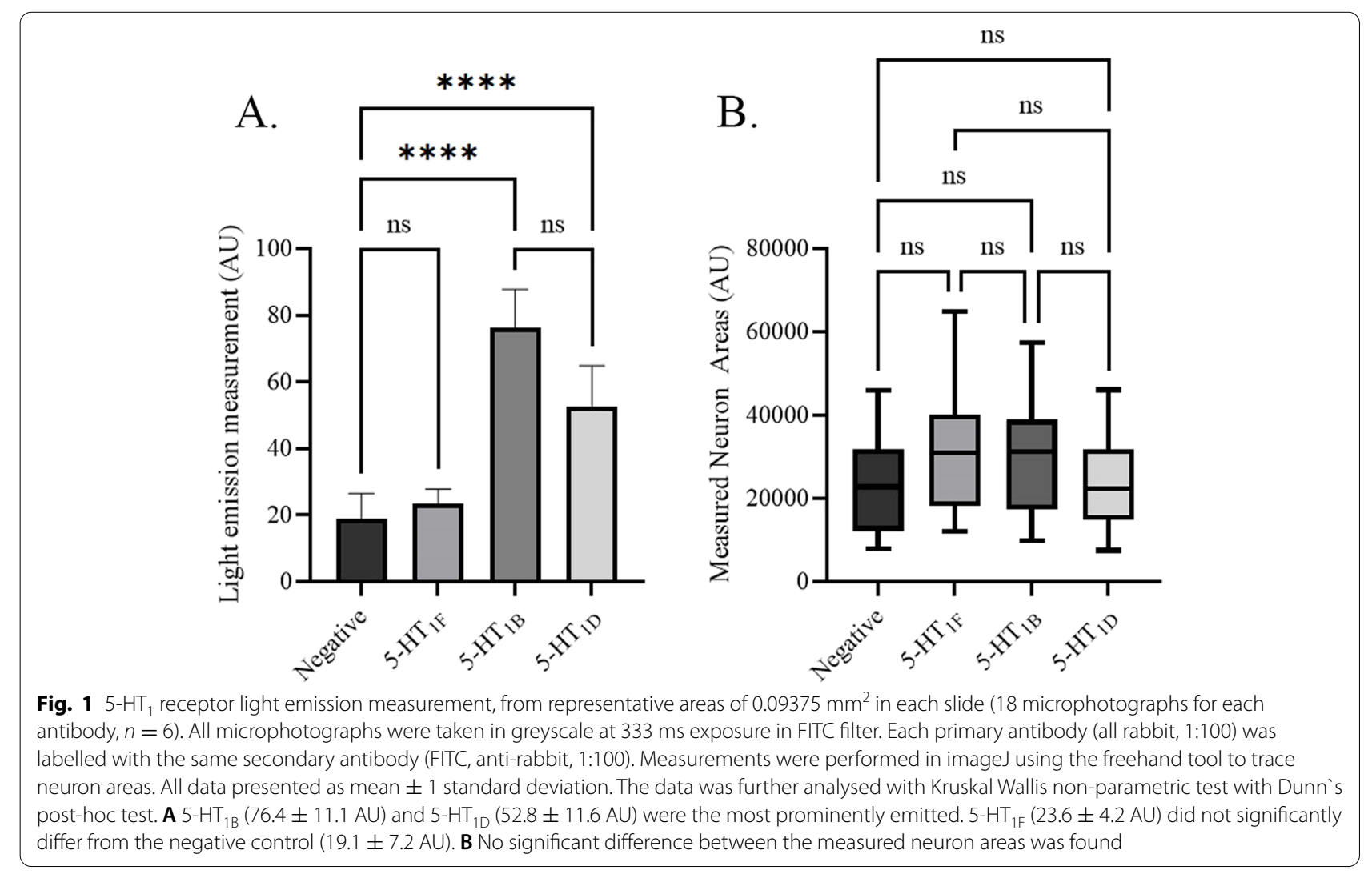



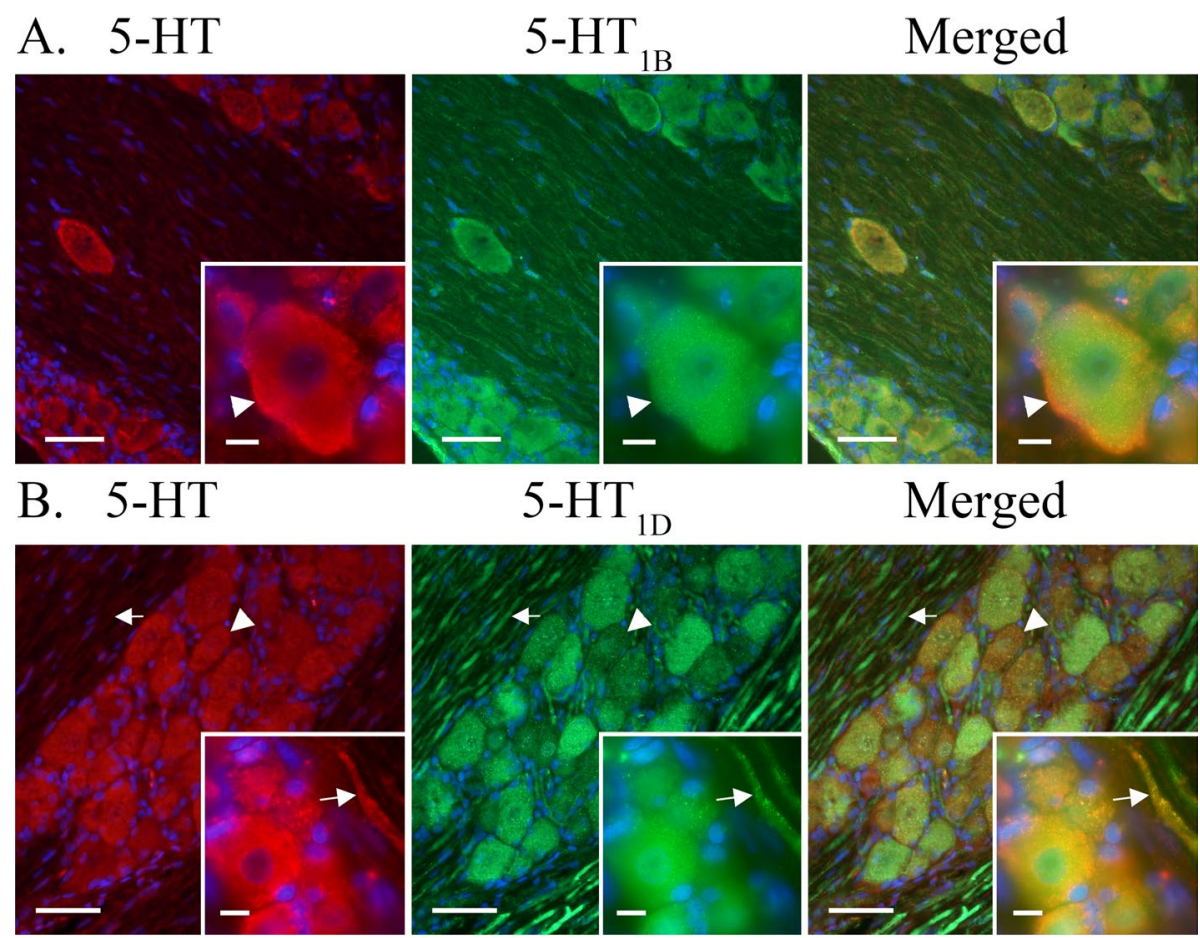

Merged

C. 5-HT
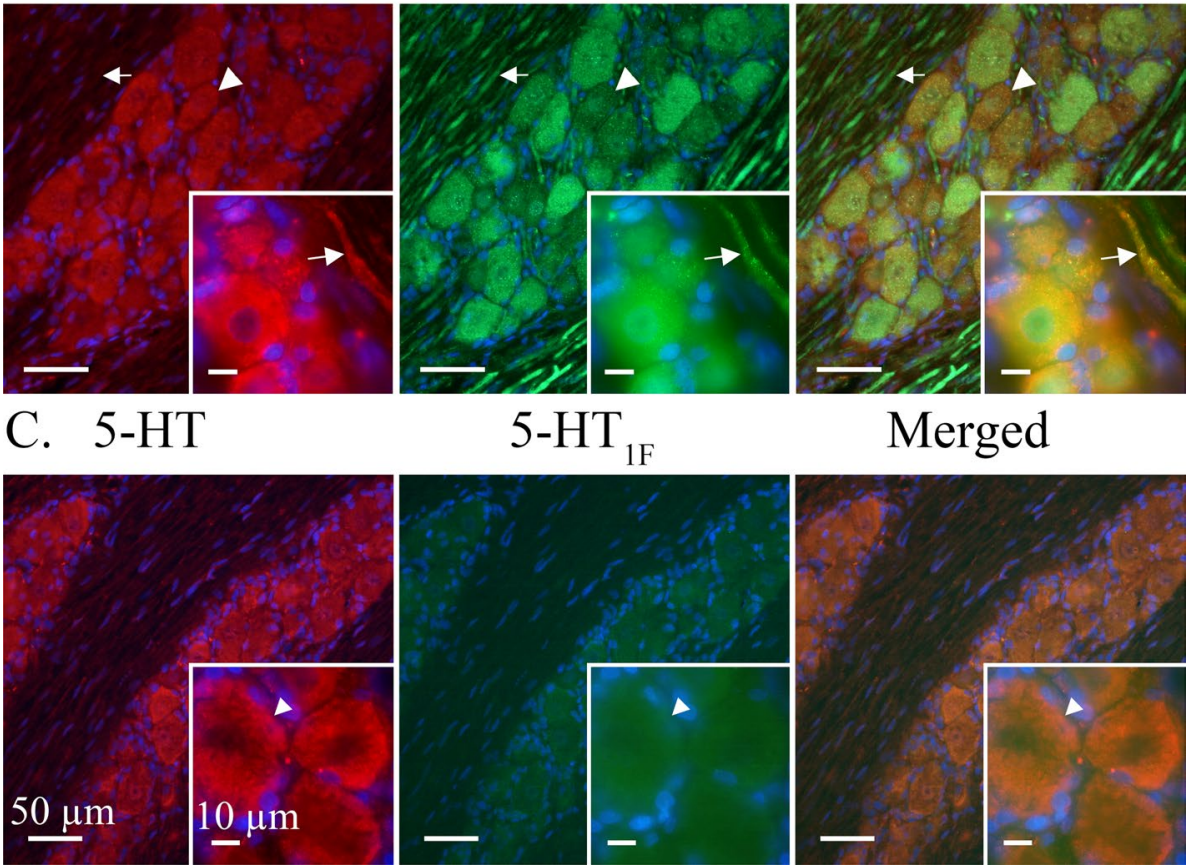

Merged

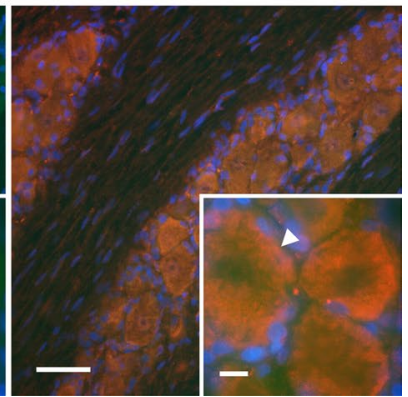

Fig. 2 Expression of 5-HT in relation to 5-HT $1 \mathrm{~B} / 1 \mathrm{D} / 1 \mathrm{~F}$ receptors. A majority of observed TG neurons expressed 5-HT-ir in a heterogeneous granular pattern. This pattern was reminiscent of cytoplasmic vesicles and which was often visualized close to the cell membrane. 5-HT was generally weakly expressed in A $\delta$-fibres, Schwann cells and satellite glial cells. A $5-\mathrm{HT}_{1 \mathrm{~B}}$ receptor ir was found in all observed neuronal cell bodies and more faintly

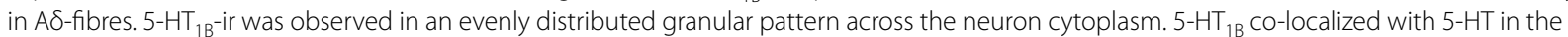
neuronal cytoplasm. Insert: Arrowheads mark a neuron where 5-HT is intensely expressed close to the cell membrane and 5- $\mathrm{HT}_{1 \mathrm{~B}}$ is more evenly distributed across the whole cell body. B A majority of observed neurons displayed 5- $\mathrm{HT}_{1 \mathrm{D}}$ receptor ir in a vesicular pattern. Unlike the intense and evenly distributed ir of 5- $\mathrm{HT}_{1 \mathrm{~B}}$ receptor, the $5-\mathrm{HT}_{1 \mathrm{D}}$ receptor displayed both strong and weak ir in different subsets of neurons. Arrowheads mark a neuron with a fainter $5-\mathrm{HT}_{1 \mathrm{D}}$ expression than a neighbouring neuron. Furthermore, $5-\mathrm{HT}_{1 \mathrm{D}}$ displayed a distinct $\mathrm{A} \delta$-fibre ir. Arrows mark a visible

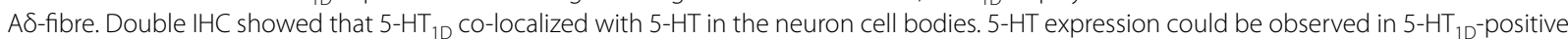

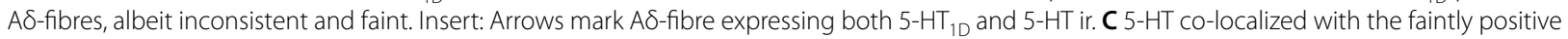
5- $\mathrm{HT}_{1 \mathrm{~F}}$ receptor in neuron cell bodies. No nerve fibre ir was observed for the 5- $\mathrm{HT}_{1 \mathrm{~F}}$ receptor. Insert: Arrowhead marks a 5-HT positive neuron with a faint $5-\mathrm{HT}_{1 \mathrm{~F}}$ expression

but did not co-localize in CGRP or SP immunoreactive C-fibres. Instead, 5-HT-ir was observed in a subset of C-fibres (Fig. 3B-C) fewer than those expressing CGRP or SP and were mainly observed proximal to the RedlichObersteiner's zone (i.e., the root entry zone). In addition, 5 -HT-ir was mainly observed in very thin $(<0.5 \mu \mathrm{m}$ in diameter) C-fibre axons, while CGRP-ir was observed in all C-fibre axon ranges $(0.2 \mu \mathrm{m}-1.5 \mu \mathrm{m}$ in diameter).

$5-\mathbf{H T}_{1 \mathrm{~B}}$-ir was detected in most observed trigeminal neuron somas. $5-\mathrm{HT}_{1 \mathrm{~B}}$-ir often presented in an evenly distributed granular pattern, reminiscent of cytoplasmic vesicles, across the neuron cytoplasm but could 

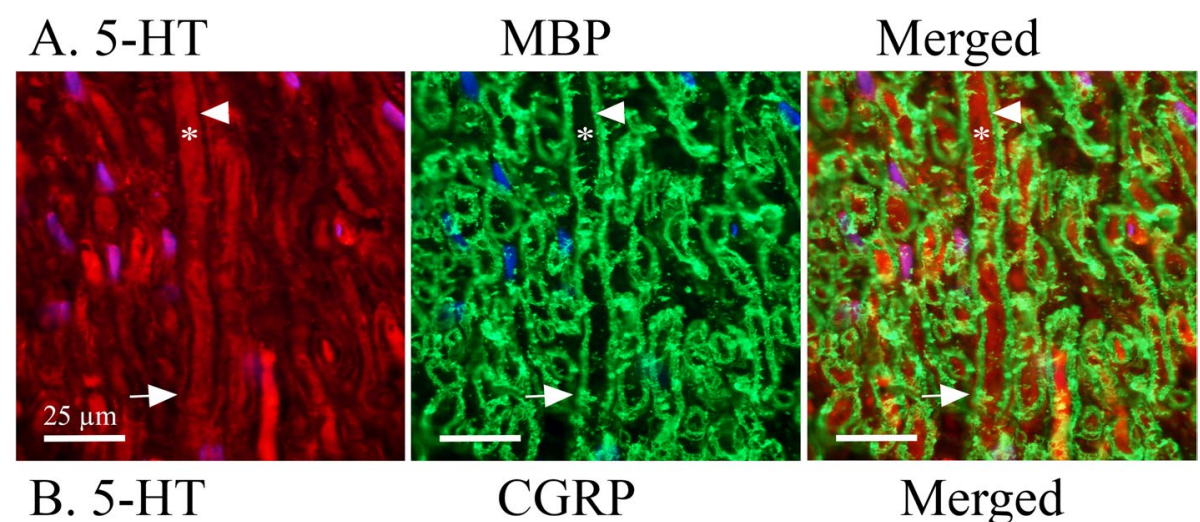

CGRP
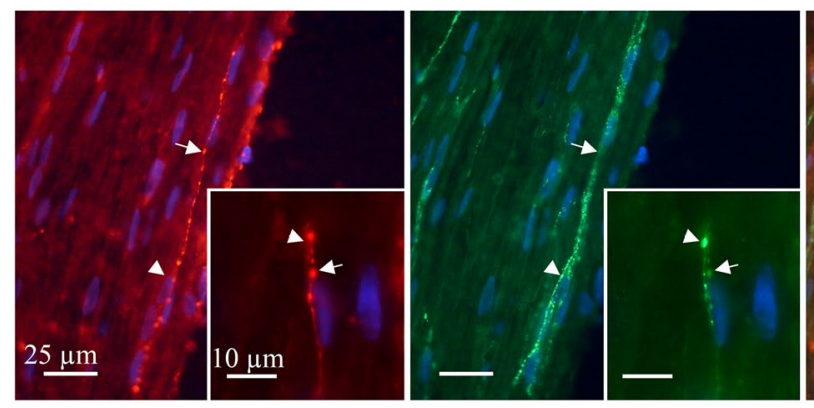

Merged

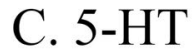

SP
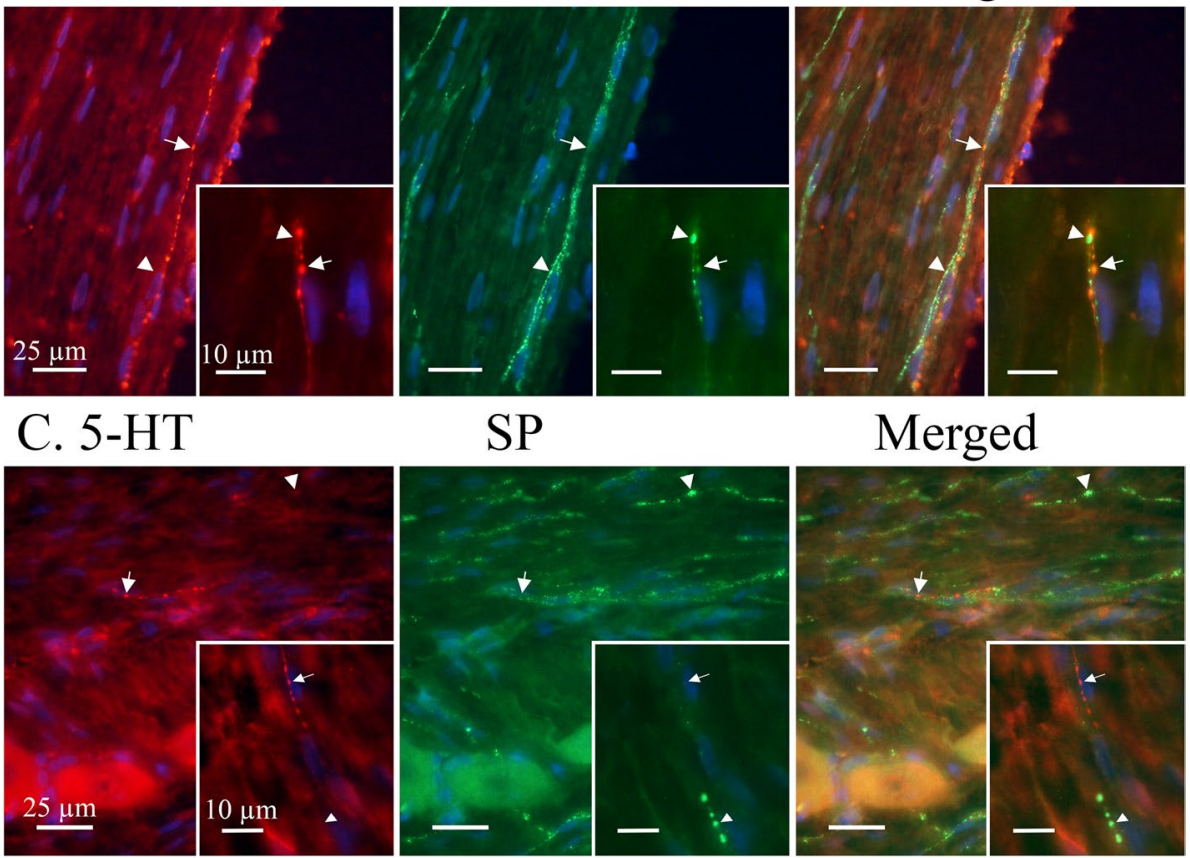

Merged

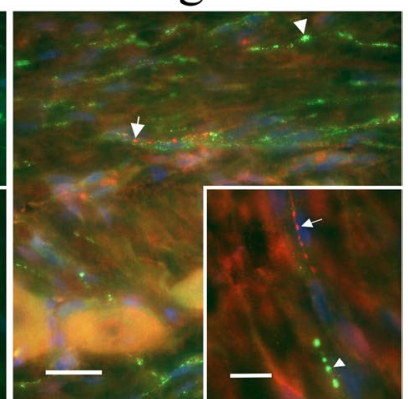

Fig. 3 Expression of 5-HT in relation to myelin basic protein (MBP), SP and CGRP. A MBP showed a distinct staining of myelin sheath flanking

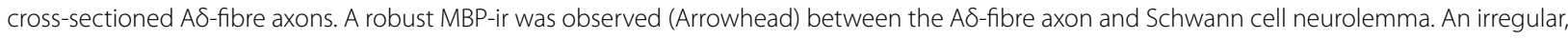
and sometimes faint, expression of 5-HT could be observed in A $\delta$-fibre axons (Asterix) and just outside the myelin sheath (Arrow), indicative for the neurolemma of the Schwann cell containing its cytoplasm. B A minority of observed C-fibres expressed 5-HT-ir, these were more frequently found in proximity to Redlich-Obersteiner's zone. CGRP-ir was more abundantly expressed in C-fibres and did not co-localize with 5-HT. Arrows mark 5-HT positive C-fibre boutons and arrowheads mark CGRP positive C-fibre boutons. Insert: Two thin C-fibres entwining and differentially expressing either CGRP or 5-HT. C Similarly, SP could be found concentrated to C-fibre boutons (Arrowhead) throughout the TG. The few 5-HT positive C-fibres (Arrow) were not found to co-localize with SP positive C-fibres. Insert: A thin C-fibre expressing 5-HT-ir (Arrow) above a seemingly larger SP positive C-fibre (Arrowhead)

sometimes be seen concentrated close to the cell membrane (Fig. 2A). In addition, $5-\mathrm{HT}_{1 \mathrm{~B}}$-ir could be faintly observed in Schwann cell neurolemma and irregularly in SGCs. Although all observed neuron cell bodies were positive for $5-\mathrm{HT}_{1 \mathrm{~B}}$ only a faint ir could be observed in $A \delta$-fibres positive for receptor activity-modifying protein 1 (RAMP1) (Fig. 4A) or contactin associated protein 1 (CASPR) (Fig. 5A). Similarly, $5-\mathrm{HT}_{1 \mathrm{~B}}$-ir was detected in CGRP positive neurons but $5-\mathrm{HT}_{1 \mathrm{~B}}$-ir was not observed in CGRP positive C-fibres (Fig 6A).

$5-\mathrm{HT}_{1 \mathrm{D}}$-ir was detected in a majority of observed trigeminal neuron somas. $5-\mathrm{HT}_{1 \mathrm{D}}$-ir was observed as a robust granular staining across the neuron or a more vesicular ir with a weaker cytoplasmic staining. In both cases, $5-\mathrm{HT}_{1 \mathrm{D}}$-ir in or around the nuclei could be observed (Fig. 2B). Furthermore, $5-\mathrm{HT}_{1 \mathrm{D}}$-ir was at times 

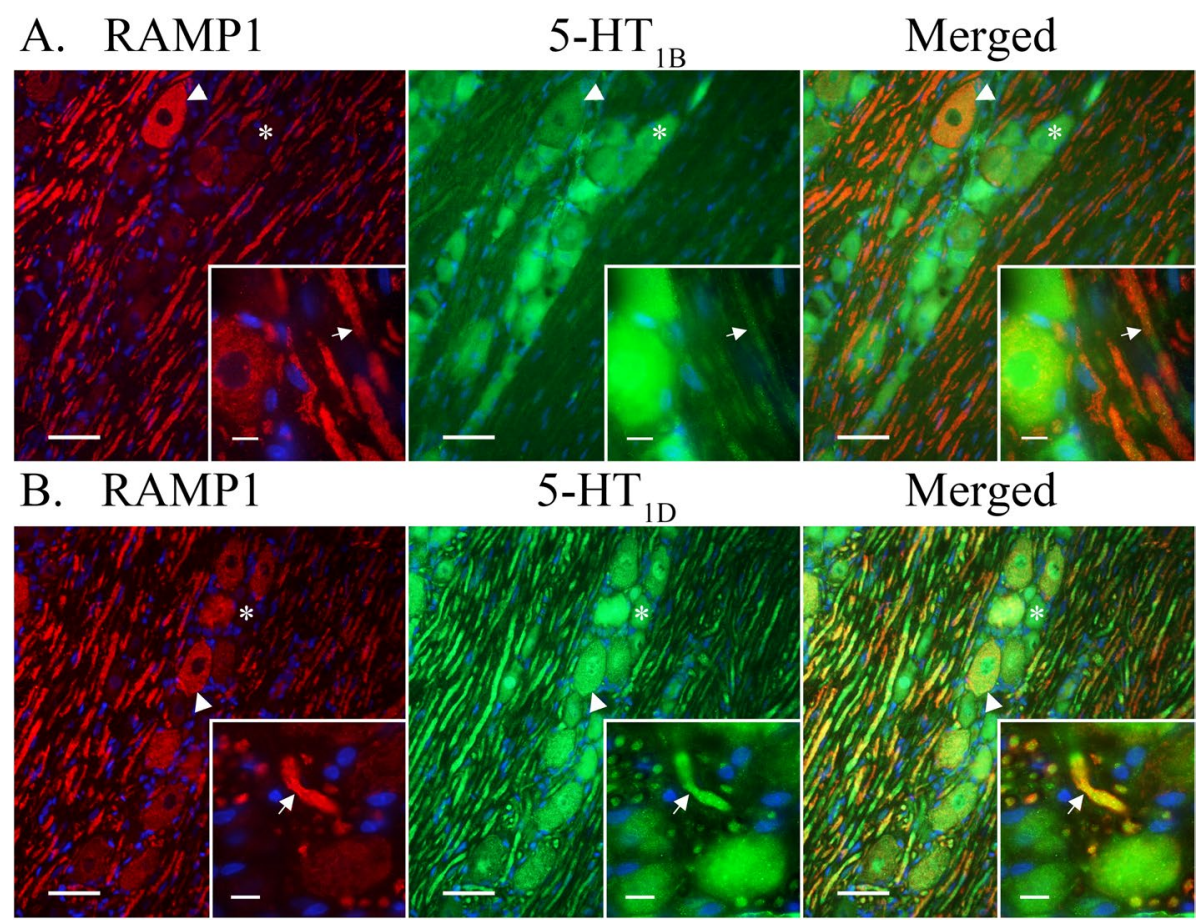

Merged

C. RAMP1

$5-\mathrm{HT}_{1 \mathrm{~F}}$
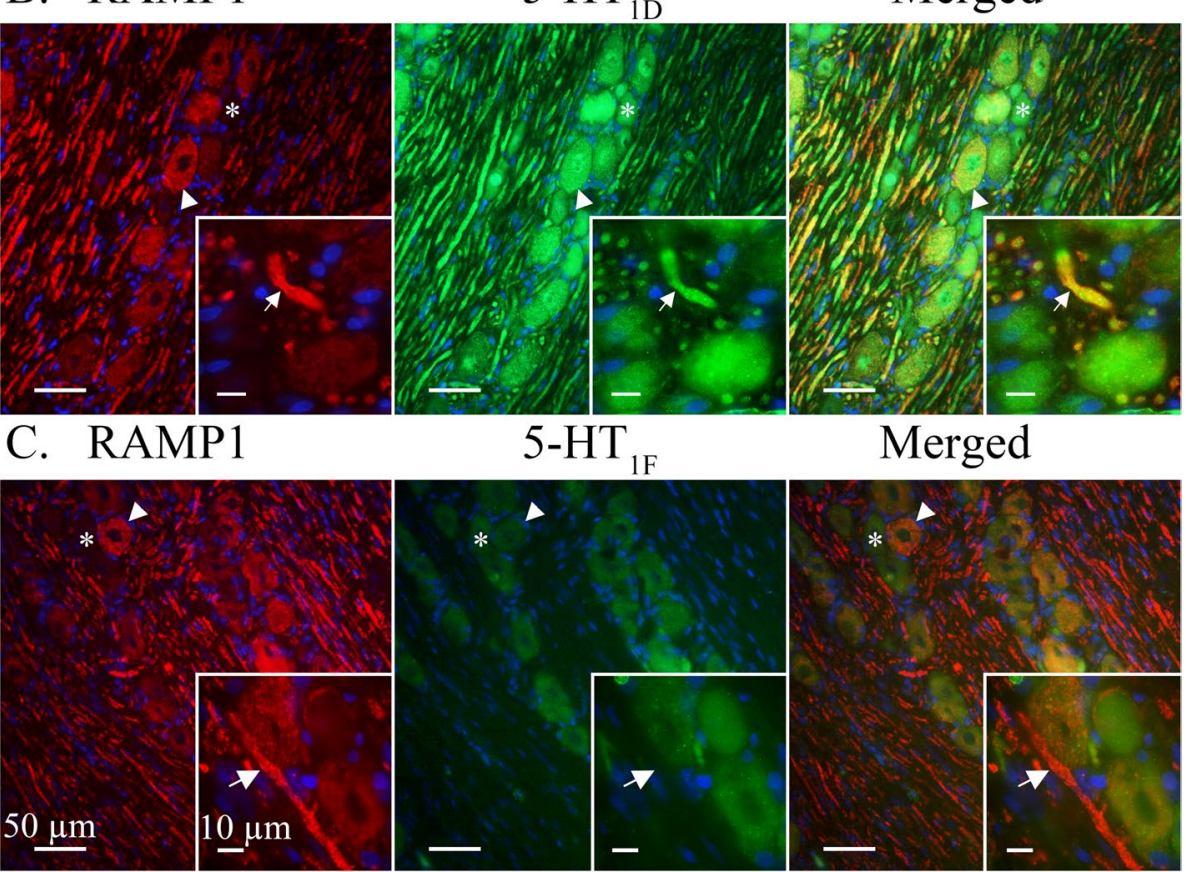

Fig. 4 Double staining CGRP receptor element RAMP1 and 5-HT $1 \mathrm{B/D} / \mathrm{F}$ receptors. RAMP1 was expressed in larger neurons cell bodies (Arrowheads) and AS-fibres (Arrows). Several 5-HT, receptor positive neurons did not display RAMP1-ir (Asterixes). A 5-HT ${ }_{1 B}$ receptor ir co-localized with RAMP1 in larger neurons (Arrowhead). A weak ir for the $5-\mathrm{HT}_{1 \mathrm{~B}}$ receptor could be detected in the RAMP1 labelled A $\delta$-fibres (Arrows). B 5-HT 1 receptor ir co-localized with RAMP1 in A $\delta$-fibres (Arrow) and larger neurons (Arrowhead). C 5-HT 1 receptors were not expressed in observed RAMP1 positive

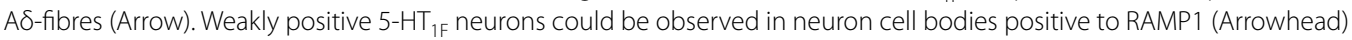

faintly observed in SGCs but was not seen in Schwann cells. In contrast to $5-\mathrm{HT}_{1 \mathrm{~B}}$-ir, $5-\mathrm{HT}_{1 \mathrm{D}}$-ir was prominently expressed in $A \delta$-fibres where it could be seen to co-localize with RAMP1 (Fig. 4B). Though expressed in the same $\mathrm{A} \delta$-fibre, $5-\mathrm{HT}_{1 \mathrm{D}}$-ir was not observed to colocalize with the integral membrane protein CASPR (Fig. 5B). In agreement with $5-\mathrm{HT}_{1 \mathrm{~B}}, 5-\mathrm{HT}_{1 \mathrm{D}}$-ir was expressed in CGRP positive neuron cell bodies but was not observed in CGRP positive C-fibres (Fig. 6B).

$5-\mathrm{HT}_{1 \mathrm{~F}}$-ir was faintly detected in all observed trigeminal neuron somas. Due to the weak expression, no clear compartmentalization within the cytoplasm could be distinguished (Fig. 2C). No ir for 5- $\mathrm{HT}_{1 \mathrm{~F}}$ was observed in SGCs or Schwann cells. Similarly, $5-\mathrm{HT}_{1 \mathrm{~F}}$ was not observed in A $\delta$-fibres, marked with RAMP1 (Fig. 4C) and CASPR (Fig. 5C), or C-fibres, marked with CGRP (Fig. 6C).

\section{$5-\mathrm{HT}_{1 \mathrm{~B}}, 5-\mathrm{HT}_{1 \mathrm{D}}$ and $5-\mathrm{HT}_{1 \mathrm{~F}}$ receptor mRNA expression in rat TG}

Levels of mRNA expression for $5-\mathrm{HT}_{1 \mathrm{~B} / 1 \mathrm{D} / 1 \mathrm{~F}}$ receptors were measured with qPCR.

The mRNA expression of $5-\mathrm{HT}_{1}$ receptor subtypes were normalized to the housekeeping gene GAPDH (Fig. 7). The experiments confirmed the mRNA expression of the $5-\mathrm{HT}_{1 \mathrm{~B}}$ receptor (Ct: $\left.23.52 \pm 0.16\right)$, the $5-\mathrm{HT}_{1 \mathrm{D}}$ receptor 

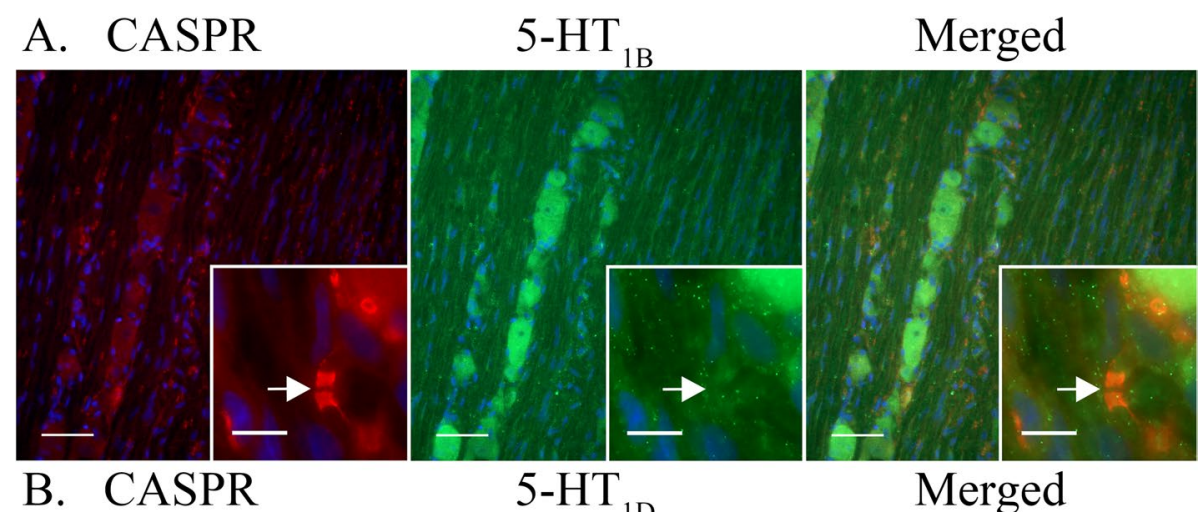

5-HT

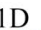

Merged
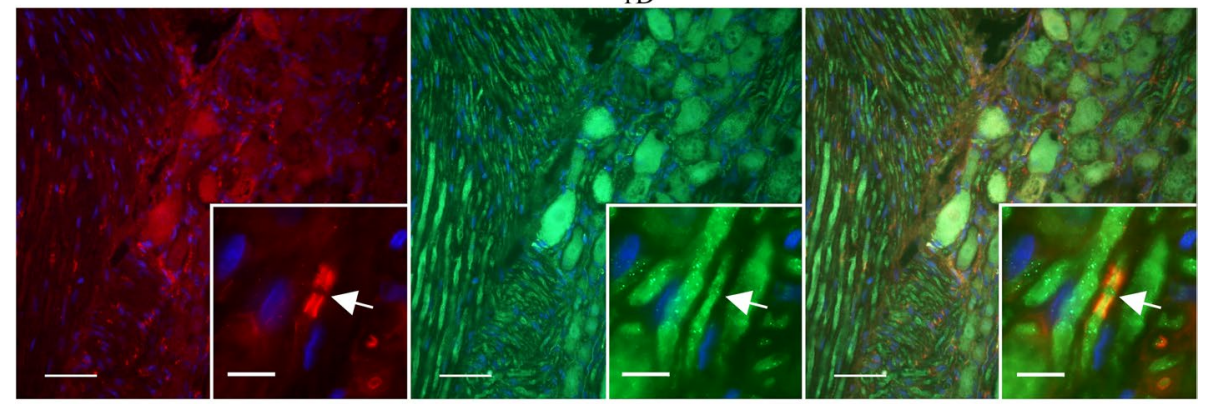

C. CASPR

5-HT
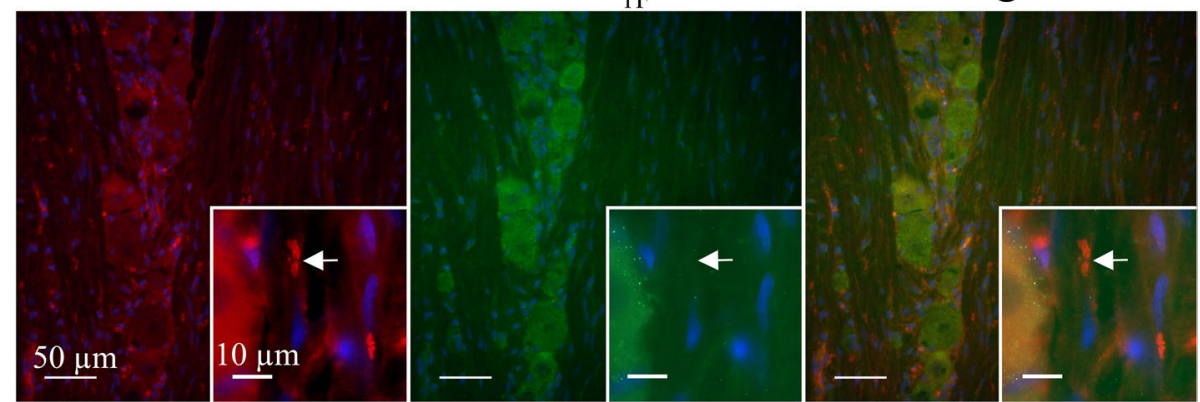

Fig. 5 5-HT $1 \mathrm{~B} / \mathrm{D} / \mathrm{F}$ receptors co-staining with the paranodal marker CASPR. Arrows mark nodes of Ranvier in CASPR labelled A $\delta$-fibres. A Ir for 5-HT $1 \mathrm{~B}$

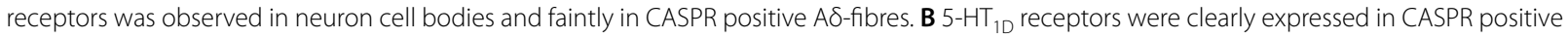
A $\delta$-fibres and neuron cell bodies. C A weak ir for $5-\mathrm{HT}_{1 \mathrm{~F}}$ receptors was detected in some neuron cell bodies while no ir was found in $\mathrm{A} \delta$-fibres

$(\mathrm{Ct}: 22.57 \pm 0.15)$ and the $5-\mathrm{HT}_{1 \mathrm{~F}}$ receptor $(\mathrm{Ct}: 25.08 \pm$ 0.41). Statistical analysis revealed significant differences between all three receptor subtypes. The $5-\mathrm{HT}_{1 \mathrm{D}}$ receptor was the most prominently expressed, followed by the $5-\mathrm{HT}_{1 \mathrm{~B}}$ receptor and lastly the $5-\mathrm{HT}_{1 \mathrm{~F}}$ receptor. In each qPCR experiment either a no template control or a minus reverse transcriptase control was included, and no signs of contamination or genomic DNA were detected in those samples.

\section{Clinical dose of Lasmiditan in relation to $\mathrm{pEC}_{50}$}

Based on the relatively low expression of the $5-\mathrm{HT}_{1 \mathrm{~F}}$ receptor in our experiments we questioned whether the full effect of Lasmiditan occurs via the $5-\mathrm{HT}_{1 \mathrm{~F}}$ receptor or if the recommended dose would allow for a less specific binding to $5-\mathrm{HT}_{1 \mathrm{~B} / \mathrm{D}}$ receptors instead. We used publicly available data on plasma concentrations of the current available $5-\mathrm{HT}_{1}$ receptor agonists and correlated this data to the $\mathrm{pEC}_{50}$ from a cyclic adenosine monophosphate (cAMP) assay [23]. For both the $5-\mathrm{HT}_{1 \mathrm{~B}}$ (Fig. 8A, $\left.\mathrm{R}^{2}=0.54, \mathrm{p}=0.01, \mathrm{n}=11\right)$ and the $5-\mathrm{HT}_{1 \mathrm{D}}\left(\right.$ Fig. $8 \mathrm{~B}, \mathrm{R}^{2}$ $=0.66, n=11, p=0.003)$ receptors the data correlated well and as expected for a targeted treatment, higher $\mathrm{pEC}_{50}$ nicely matched with a lower plasma concentration. In contrast to $5-\mathrm{HT}_{1 \mathrm{~B}}$ and $5-\mathrm{HT}_{1 \mathrm{D}}$, the $\mathrm{pEC}_{50}$ for the $5-\mathrm{HT}_{1 \mathrm{~F}}$ receptor did not correlate significantly with the plasma concentration $\left(\mathrm{R}^{2}=0.17, n=10, p=0.24\right)$, and if anything the correlation was negative (Fig. 8C). 

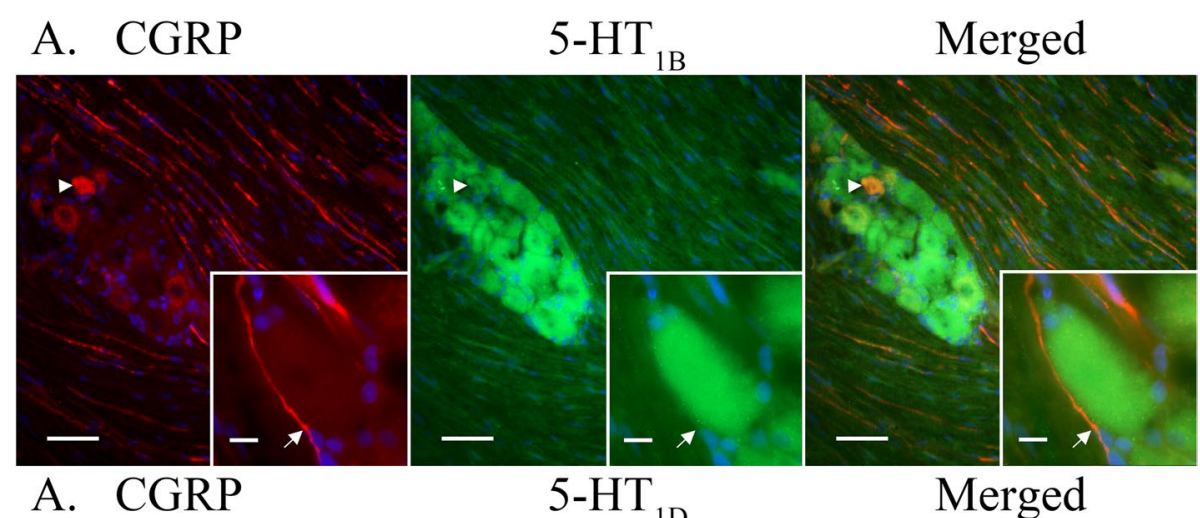

$5-\mathrm{HT}$ $1 \mathrm{D}$

\section{Merged}
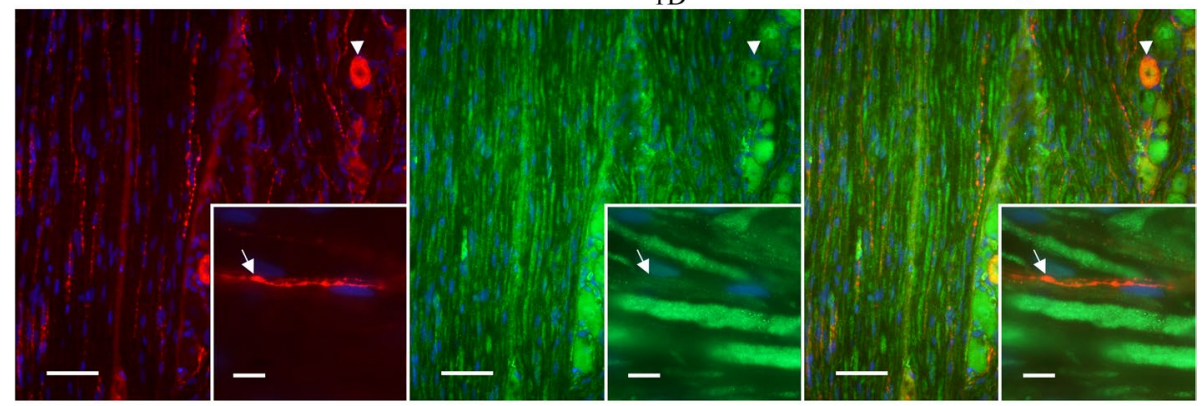

A. CGRP

$5-\mathrm{HT}_{1}$
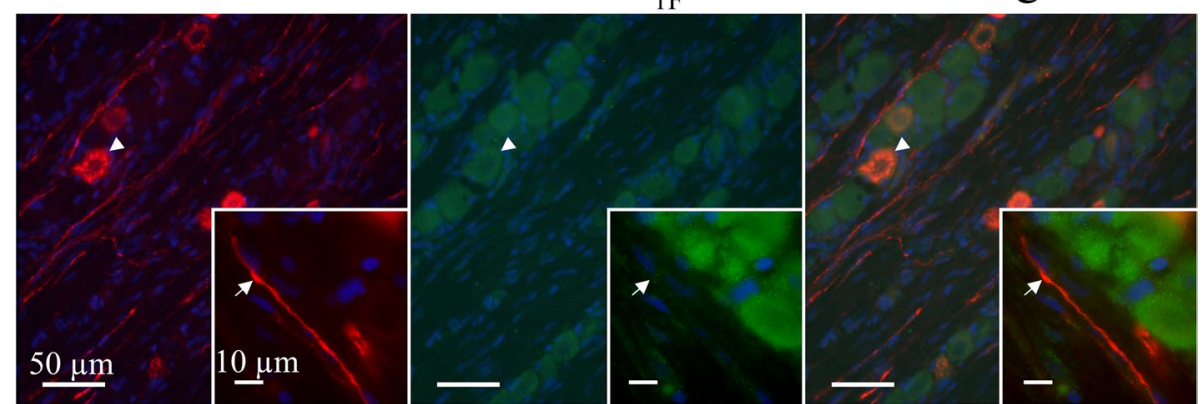

Fig. 6 5-HT $1 \mathrm{~B} / \mathrm{D} / \mathrm{F}$ receptors Co-staining with CGRP. CGRP-ir revealed a vesicular staining pattern in neuron cell bodies and C-fibres. A CGRP co-localized with $5-\mathrm{HT}_{1 \mathrm{~B}}$ receptors in some neuron cell bodies (Arrowhead). No expression of the $5-\mathrm{HT}_{1 \mathrm{~B}}$ receptor was observed in CGRP positive C-fibres. Insert: CGRP immunoreactive C-fibre adjacent to 5- $\mathrm{HT}_{1 \mathrm{~B}}$ positive neuron cell body. Arrow marks a visible C-fibre bouton. B CGRP-ir co-localized with 5- $\mathrm{HT}_{1 \mathrm{D}}$ in neuron cell bodies (Arrowhead). No expression of the 5- $\mathrm{HT}_{1 \mathrm{D}}$ receptor was detected in the CGRP immunoreactive C-fibres. Insert: CGRP positive C-fibre intermingled between 5-HT 1 D positive AS-fibres. Arrow marks a visible C-fibre bouton. C CGRP co-localized with weakly positive $5-\mathrm{HT}_{1 \mathrm{~F}}$ receptors in neuron somas. No expression of the $5-\mathrm{HT}_{1 \mathrm{~F}}$ receptor was detected in C-fibres. Insert: CGRP positive C-fibre in proximity to $5-\mathrm{HT}_{1 \mathrm{~F}}$ positive neuron cell bodies. Arrow marks a visible C-fibre bouton

Interestingly, Lasmiditan (the red square) is located on the linear trend of both $5-\mathrm{HT}_{1 \mathrm{~B}}$ and $5-\mathrm{HT}_{1 \mathrm{D}}$ receptors suggesting that the plasma concentration achieved in the clinical studies is high enough to activate these receptors. These results suggest that a considerable part of the anti-migraine effect of Lasmiditan is mediated through $5-\mathrm{HT}_{1 \mathrm{~B}}$ and/or $5-\mathrm{HT}_{1 \mathrm{D}}$ receptor activation.

\section{CGRP release experiments and the effect of Lasmiditan}

To confirm that Lasmiditan also inhibits CGRP release in the hemi-skull model in rats similar to in mice [24], the cranial cups were pre-treated with $30 \mu \mathrm{M}$ Lasmidi$\tan$ and stimulated with $60 \mathrm{mM} \mathrm{K}^{+}$(Fig. 9). Similar to in the mice model, Lasmiditan inhibited CGRP release significantly in the dura (Fig. 9A, $172 \pm 11 \mathrm{pg} / \mathrm{mL}$ vs $115 \pm 20 \mathrm{pg} / \mathrm{mL}, n=5, p=0.032)$ and in the TG (Fig. 9B, $144 \pm 11 \mathrm{pg} / \mathrm{mL}$ vs $113 \pm 10 \mathrm{pg} / \mathrm{mL}, n=5, p$ $=0.039)$.

GR127935, a mixed 5- $\mathrm{HT}_{1 \mathrm{~B} / 1 \mathrm{D}}$ antagonist, was added at different concentrations to evaluate if blocking these receptors would counter-act the inhibitory effect of Lasmiditan on CGRP release. For the data on the 


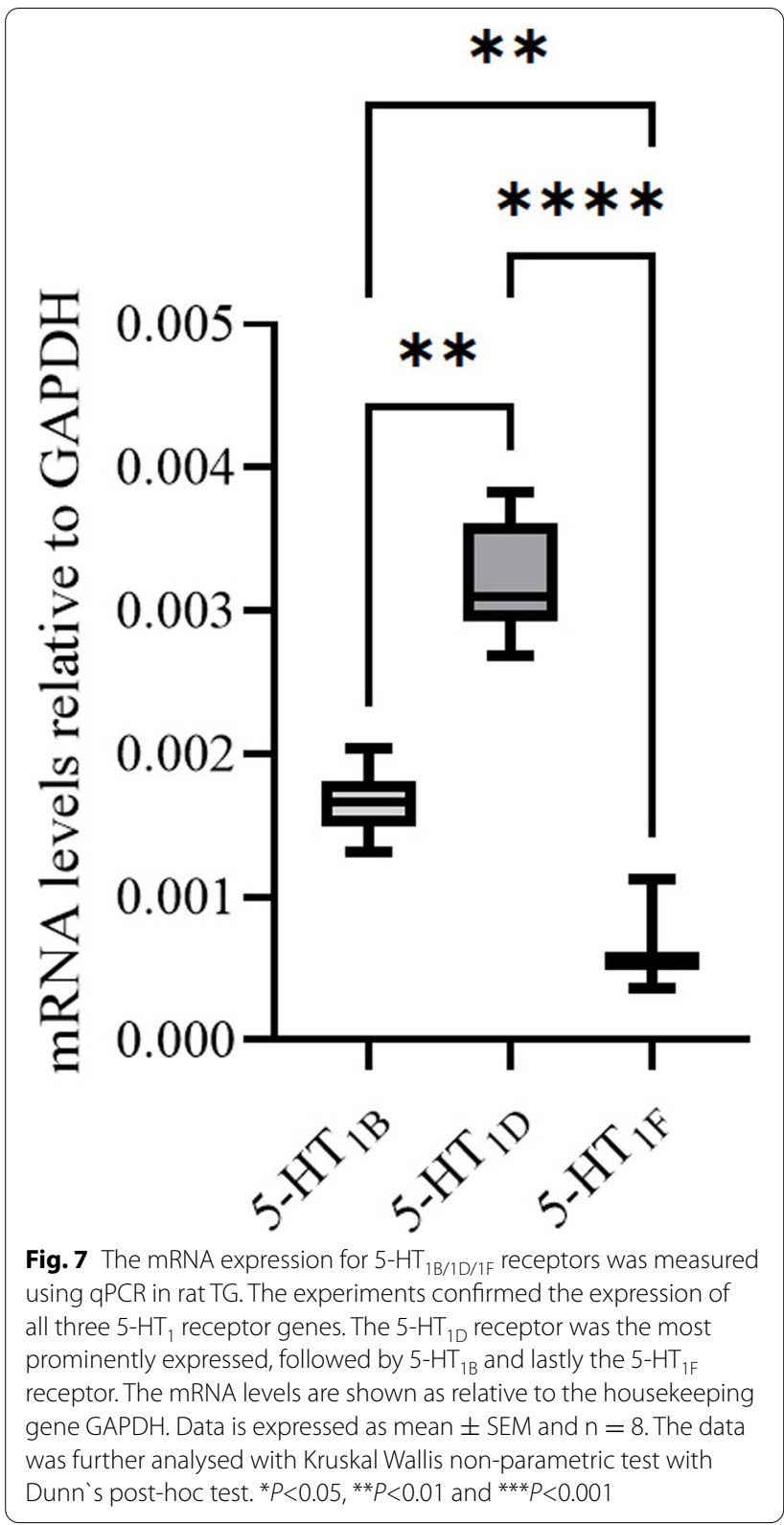

dura, we did not see any effect at 100 nM GR127935 (Fig. 10A), however we observed a weak effect at 300 nM GR127935 (Fig. 10B, $98 \pm 10 \mathrm{pg} / \mathrm{mL}$ vs $105 \pm 10$ $\mathrm{pg} / \mathrm{mL}, n=6, p=0.15)$, but increasing the concentration did not augment this effect (Fig. 10C).

In the TG, $100 \mathrm{nM}$ of GR127935 did not show significant effect (Fig. 10D, $132 \pm 22 \mathrm{pg} / \mathrm{mL}$ vs $148 \pm 28 \mathrm{pg} / \mathrm{mL}$, $n=5, p=0.28) .300 \mathrm{nM}$ showed significantly restored CGRP release (Fig. 10E, $92 \pm 11 \mathrm{pg} / \mathrm{mL}$ vs $134 \pm 17 \mathrm{pg} /$ $\mathrm{mL}, n=16, p=0.014)$, whereas $1 \mu \mathrm{M}$ of GR $127935 \mathrm{had}$ no effect (Fig. 10F, $134 \pm 21 \mathrm{pg} / \mathrm{mL}$ vs $93 \pm 6 \mathrm{pg} / \mathrm{mL}, n$ $=6, p=0.2$ ). If anything, GR127935 had an additional inhibitory effect suggesting it works as a partial agonist at the high concentration, as has been documented [34], or potentially interfering with the $5-\mathrm{HT}_{3}$ receptor system [35]. GR127935 was further evaluated on its own and no effects per se were observed (Suppl. Fig. 1).

As we observed the strongest correlation of our data on the $5-\mathrm{HT}_{1 \mathrm{D}}$ receptor, BRL15572, a $5-\mathrm{HT}_{1 \mathrm{D}}$ specific antagonist, was also tested at $1.25 \mu \mathrm{M}$ (Suppl. Fig. 2). This antagonist produced an additional inhibition of CGRP release in the dura (Suppl. Fig. 2A, $91 \pm 17 \mathrm{pg}$ / $\mathrm{mL}$ vs $64 \pm 6 \mathrm{pg} / \mathrm{mL}, n=5, p=0.046)$. BRL15572 is likely acting as a partial agonist [34], but showed no effect in the TG (Suppl. Fig. 2B, $145 \pm 11$ pg/mL vs 126 $\pm 13 \mathrm{pg} / \mathrm{mL}, n=5, p=0.34$ ), however this was not pursued further.

\section{Release of 5-HT from the TVS}

Although the most commonly used anti-migraine drugs are targeting the $5-\mathrm{HT}$ signaling system, nearly no data on its intrinsic role in the TG exist. The IHC data revealed the presence of several 5-HT-ir fibres in the TG. The study therefore opted to investigate potential 5-HT release from the TVS (Fig. 11). Release was stimulated with $60 \mathrm{mM} \mathrm{K}^{+}$(Fig. 11A) or $100 \mathrm{nM}$ Capsaicin (Fig. 11B). The CGRP release data was collected in parallel as a comparative. 5-HT was observed above the detection limit in all samples, but was not found to be released from the dura $(0.59 \pm 0.04 \mathrm{ng} / \mathrm{mL}$ to $0.60 \pm$ $0.03 \mathrm{ng} / \mathrm{mL}, n=6, p=0.78)$ nor was it released from the soma-poor TG $(0.54 \pm 0.08 \mathrm{ng} / \mathrm{mL}$ to $0.51 \pm 0.03$ $\mathrm{ng} / \mathrm{mL}, n=5, p=0.88)$. 5 -HT was only detected to be released at levels higher than baseline in the soma-rich TG $(0.48 \pm 0.06 \mathrm{ng} / \mathrm{mL}$ to $0.58 \pm 0.08 \mathrm{ng} / \mathrm{mL}, n=6$, $p=0.06$ ), which coincidentally is where most of the 5-HT-ir C-fibres were observed. For the data on stimulation with capsaicin, the 5 -HT levels were slightly lower in the dura $(0.68 \pm 0.15 \mathrm{ng} / \mathrm{mL}$ to $0.48 \pm 0.03 \mathrm{ng} /$ $\mathrm{mL}, n=7, p=0.17)$, soma-poor TG $(0.53 \pm 0.05 \mathrm{ng} / \mathrm{mL}$ to $0.45 \pm 0.05 \mathrm{ng} / \mathrm{mL}, n=5, p=0.012)$ and soma-rich TG $(0.62 \pm 0.08 \mathrm{ng} / \mathrm{mL}$ to $0.52 \pm 0.05 \mathrm{ng} / \mathrm{mL}, n=6, p$ $=0.018)$. In the soma-rich TG there was a significantly higher 5-HT release following the $60 \mathrm{mM} \mathrm{K}^{+}$compared to the $100 \mathrm{nM}$ Capsaicin $(0.58 \pm 0.08 \mathrm{ng} / \mathrm{mL}$ vs $0.52 \pm$ $0.05 \mathrm{ng} / \mathrm{mL}, n=6, p=0.02$ ).

The 5-HT concentrations were correlated with the CGRP concentrations in the parallel samples. Interestingly, the 5-HT concentration showed significantly negative correlation (Fig. $12 \mathrm{~A}, \mathrm{R}^{2}=0.25, n=34, p=$ 0.002) with CGRP in all baseline samples. This indicates that 5-HT is a natural inhibitor of basal CGRP levels. Although the correlation holds for all samples being combined, the trend was not significant for the dura $\left(R^{2}\right.$ $=0.07, n=12, p=0.42$ ), and only near significant for 

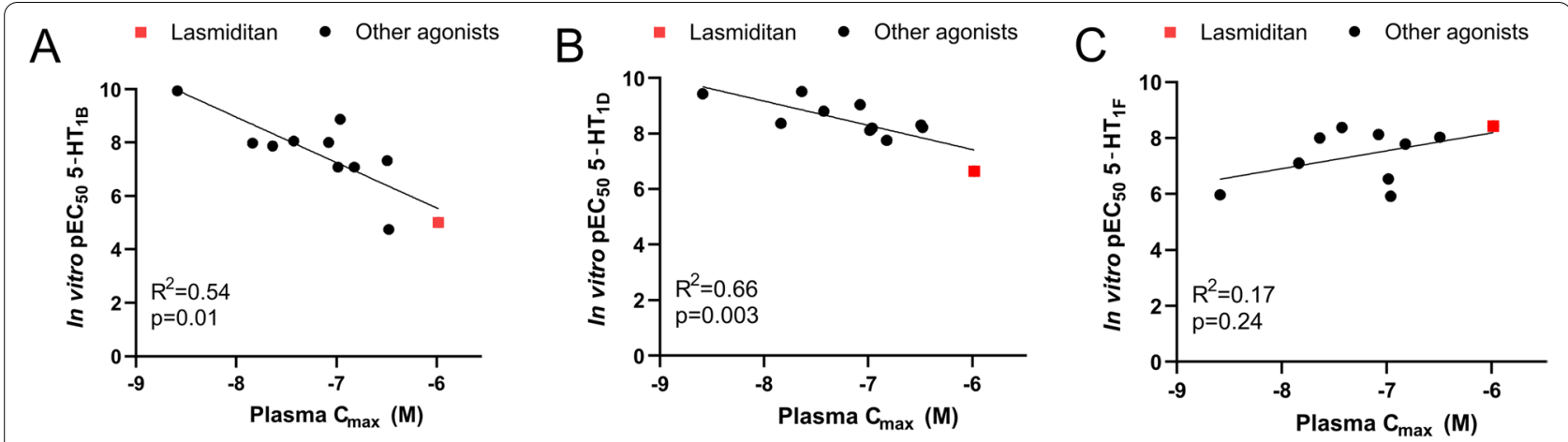

Fig. 8 Correlation data for in vitro $p E C_{50}$ versus the clinical plasma concentration $C_{\max }$ for multiple triptans and ditans. A significant correlation was observed between the $\mathrm{C}_{\max }$ and $\mathrm{pEC} \mathrm{C}_{50}$ for the $5-\mathrm{HT}_{1 \mathrm{~B}}$ receptor $(\mathbf{A})$, and $5-\mathrm{HT}_{1 \mathrm{D}}$ receptor $(\mathbf{B})$ but not $5-\mathrm{HT}_{1 \mathrm{~F}}$ receptor $(\mathbf{C})$. Worth noticing is the correlation being negative for $5-\mathrm{HT}_{1 \mathrm{~B}}$ receptor and $5-\mathrm{HT}_{1 \mathrm{D}}$ receptor, meaning that the more potent against needed lower $\mathrm{C}_{\max }$ for clinical effect, opposite to the $5-\mathrm{HT}_{1 \mathrm{~F}}$ receptor correlations. Data is displayed as individual data points with $\mathrm{p}$-values and $\mathrm{R}^{2}$ obtained from the correlation analysis. The $\mathrm{pEC}_{50}$ data points are from [23] and detailed references and data points for the $C_{\max }$ can be found in Supplementary Table 1
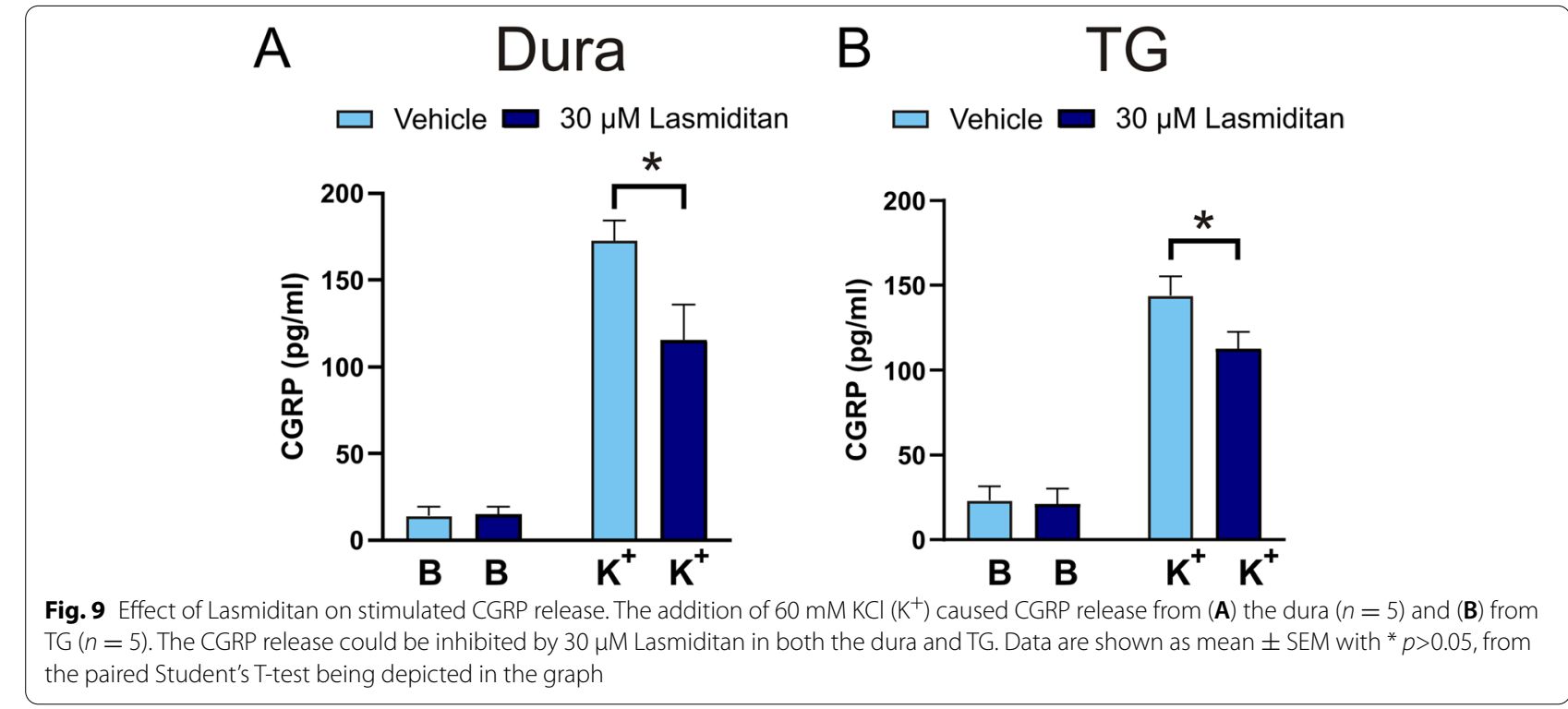

the soma-poor TG $\left(\mathrm{R}^{2}=0.37, n=10, p=0.06\right)$ by themselves. In contrast, the correlation for the soma-rich TG was found to be significant (Fig. 12B, $\mathrm{R}^{2}=0.37, n=12$, $p=0.04)$. For the $60 \mathrm{mM} \mathrm{K} \mathrm{K}^{+}$stimulation and $100 \mathrm{nM}$ Capsaicin, we did not observe any significant correlation when all samples were combined. However, significant positive correlation with $60 \mathrm{mM} \mathrm{K}^{+}$simulation (Fig. 12C, $\mathrm{R}^{2}=0.68, n=6, p=0.04$ ) was observed for the somarich TG, where 5-HT released was detected, suggesting the possibility of a negative feedback on the CGRP release. This contrasts to the data on capsaicin, here the data negatively correlate (Fig. $12 \mathrm{D}, \mathrm{R}^{2}=0.77, n=6, p=$ 0.02 ), suggesting that capsaicin stimulation potentially stimulates 5-HT uptake or breakdown.

\section{Discussion}

This study reveals the expression of 5-HT-ir throughout in the rat TG and most interestingly in a subpopulation of C-fibres lacking both CGRP- and SP-ir. In addition, we have demonstrated the differential expression of the $5-\mathrm{HT}_{1 \mathrm{~B} / 1 \mathrm{D} / 1 \mathrm{~F}}$ receptors in the TVS, which markedly add to understanding of the clinical responses to triptans and ditans.

The immunohistochemical findings reveal that 5-HT in the TG seems to be robustly expressed in a small subset of thin C-fibres and in the majority of neuron cell bodies. A weak and often patchy ir for 5-HT was also found in A $\delta$-fibres, Schwann cells and SGCs. Interestingly, the C-fibres expressing 5-HT were more frequently found 


\section{Dura}

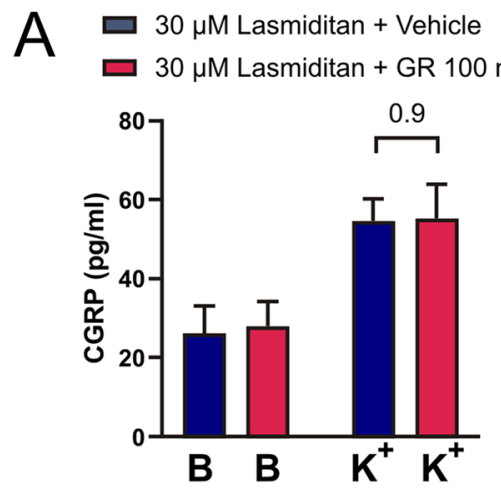

$\square \square 30 \mu \mathrm{M}$ Lasmiditan + Vehicle
$\square 30 \mu \mathrm{M}$ Lasmiditan + GR $100 \mathrm{nM}$

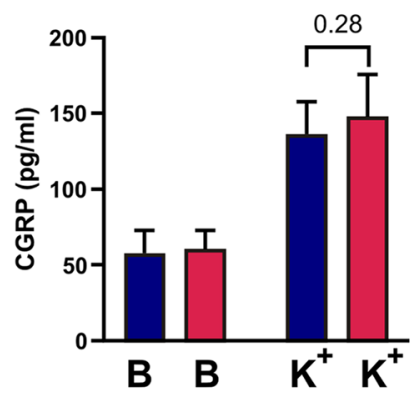

B $\square 30 \mu \mathrm{M}$ Lasmiditan + Vehicle
$\square 30 \mu \mathrm{M}$ Lasmiditan + GR $300 \mathrm{nM}$
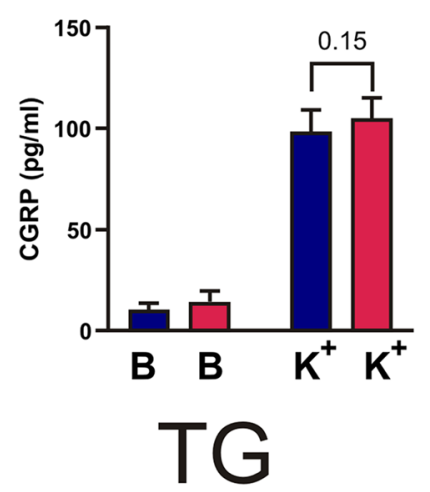

Eロ

$30 \mu \mathrm{M}$ Lasmiditan + Vehicle

$30 \mu \mathrm{M}$ Lasmiditan + GR $300 \mathrm{nM}$

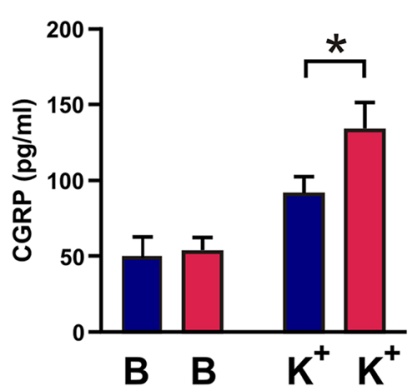

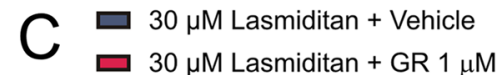

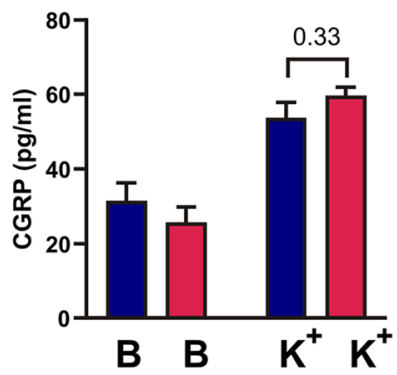

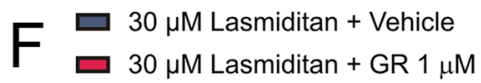

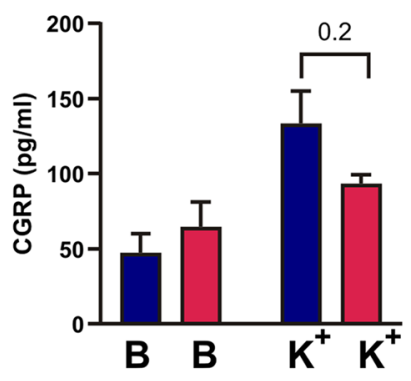

Fig. 10 The involvement of $5-\mathrm{HT}_{1 \mathrm{~B}}$ and $5-\mathrm{HT}_{1 \mathrm{D}}$ receptors on the inhibitory effect of Lasmiditan. Ten minutes before the addition of $30 \mu \mathrm{M}$ Lasmiditan: (A) $100 \mathrm{nM}(n=4)$, (B) $300 \mathrm{nM}(n=6)$ or (C) $1 \mu \mathrm{M}(n=5)$ of GR127935, a 5-HT $1 \mathrm{~B} / 5-\mathrm{HT}_{1 \mathrm{D}}$ blocker was added to the dura which subsequently stimulated with $60 \mathrm{mM} \mathrm{KCl}\left(\mathrm{K}^{+}\right)$. Similarly, 10 minutes before the addition of $30 \mu \mathrm{M}$ Lasmiditan, and before the addition of $60 \mathrm{mM} \mathrm{KCl}\left(\mathrm{K}^{+}\right)(\mathbf{D}) 100$ $\mathrm{nM}(n=5),(\mathbf{E}) 300 \mathrm{nM}(n=16)$ or $(\mathbf{F}) 1 \mu \mathrm{M}(n=6)$ of $\mathrm{GR} 127935$, was added to the TGs which subsequently stimulated with $60 \mathrm{mM} \mathrm{KCl}\left(\mathrm{K}^{+}\right)$. The

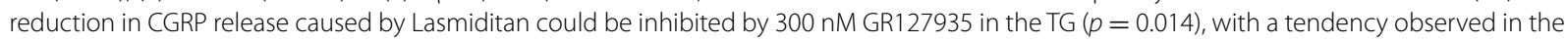
dura at the same concentration. Data are shown as mean \pm SEM with * $p>0.05$, from the paired Student's T-test being depicted in the graph
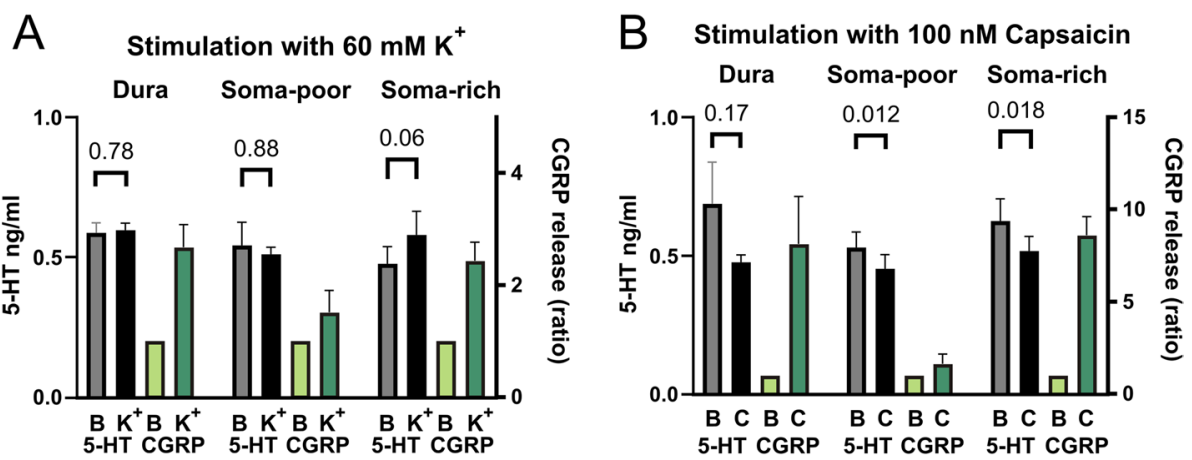

Fig. 11 Stimulated release of 5-HT and CGRP in TG and dura mater. A The addition of $60 \mathrm{mM} \mathrm{KCl}\left(\mathrm{K}^{+}\right)$caused no 5-HT release from the dura $(n=$ 6) or soma-poor TG $(n=5)$, but a significant release was seen from the soma-rich TG $(n=6)$. B The addition of $100 \mathrm{nM}$ capsaicin caused no 5 -HT release from the dura $(n=7)$, soma-poor $(n=5)$ or soma right TG $(n=6)$. In contrast a significant reduction in 5-HT was observed for both the soma-poor and soma-rich TG. For all the samples CGRP content was also measured and used for the correlation analysis. Data are shown as mean \pm SEM or their individual data points with pairing, and with $p$ values obtained with Student's T-test being depicted in the graph 

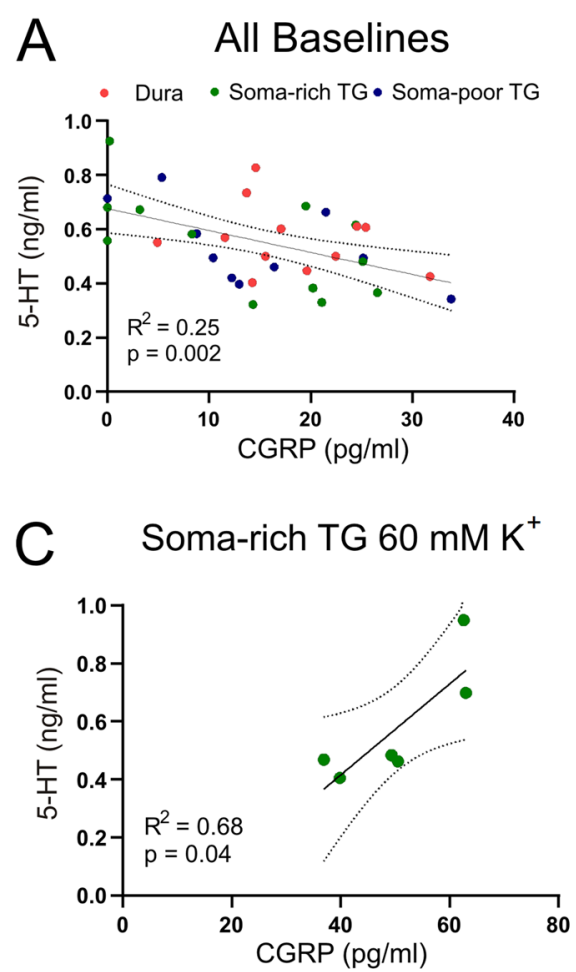

B Soma-rich TG Baselines

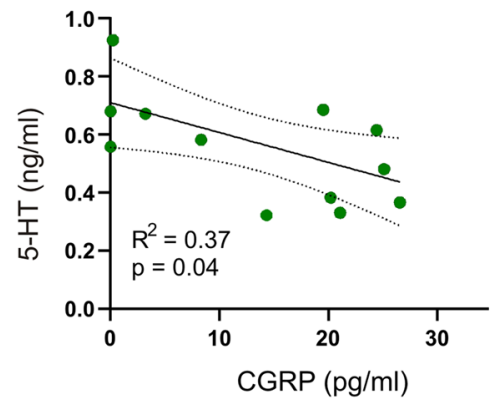

D Soma-rich TG Capsaicin

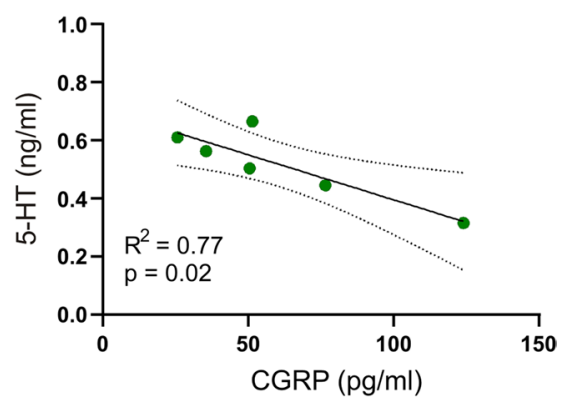

Fig. 12 Correlation of in situ 5-HT and CGRP release from the same dural or trigeminal ganglion samples. A Correlations of constitutive release (all baseline measurements) from the dura, soma-poor and soma rich TG. A significant negative correlation was observed. B Correlations of constitutive release from the soma-rich TG only, and here a significant negative correlation was observed. C The stimulated release (addition of $60 \mathrm{mM} \mathrm{KCl}\left(\mathrm{K}^{+}\right)$ or (D) $100 \mathrm{nM}$ capsaicin, of 5-HT and CGRP from the same soma-rich TGs. Significant positive correlation was observed for $\mathrm{K}^{+}$which contrasts to negative correlation observed with capsaicin. Data are shown as individual data points with $p$ values and $R^{2}$ obtained from the correlation analysis

near Redlich-Obersteiner's zone and was rarely found in distal parts of the TG, suggesting that the fibres may be projecting from the brainstem and terminating in the TG. The 5-HT-ir C-fibres presented varicosities and were often markedly thinner than the observed CGRP and SP-ir in C-fibres. This has, to our knowledge, only been observed previously in cat TG, where the thin fibres were remarkably found to encircle some TG neurons [36].

The varied staining intensity and sporadic expression of 5-HT in the A $\delta$-fibres and non-neuron cells support a potential hypothesis of 5-HT reuptake released from e.g. plasma, platelets and mast cells [37]. This agrees well with previous studies reporting low levels of TPH [29, 30]. Although we found TG neurons and fibres expressing 5 -HT, it is to the best of our knowledge not known if these cells can release 5-HT in the TG. To gain further insight into this question, we performed stimulated release experiments on 5-HT and CGRP (Fig. 11). We were only able to trigger 5 -HT release from the somarich part of the TG, which interestingly is where most 5-HT containing C-fibres were observed. Furthermore, it is plausible that the relatively high 5 -HT baseline may mask the presumed stimulated release from the subset of thin C-fibres ir to 5 -HT, which likely is quite low given the small number and diameter of these fibres.

The $5-\mathrm{HT}_{1 \mathrm{D}}$ receptor expression was observed in neuron cell bodies, often presented with a clear nuclear staining, and in A $\delta$-fibres, where it co-localized with RAMP1. No $5-\mathrm{HT}_{1 \mathrm{D}}$ receptor ir was detected in CGRP-positive C-fibres. In contrast, the $5-\mathrm{HT}_{1 \mathrm{~F}}$ receptor ir was only faintly observed in some neuron cell bodies. This low expression was confirmed with semi quantitative light emission measurements where $5-\mathrm{HT}_{1 \mathrm{~F}}$ ir did not significantly differentiate from the negative control (Fig. 1) and showed a sparse expression in the qPCR analysis (Fig. 7).

$5-\mathrm{HT}_{1 \mathrm{~B}}$ receptor expression was found in neuron cell bodies and to some extent in A $\delta$-fibres, in accordance with previous studies utilizing the same antibodies [38]. The A $\delta$-fibre expression of the $5-\mathrm{HT}_{1 \mathrm{~B}}$ receptor was confirmed by the co-localization of RAMP1 and CASPR marking the same fibre [39]. The weak $5-\mathrm{HT}_{1 \mathrm{~B}}$ receptor expression in $A \delta$-fibres may indicate that the more dominantly expressed $5-\mathrm{HT}_{1 \mathrm{D}}$ receptor may be responsive for the triptan counteraction on the CGRP activated 
cAMP-pathway in TG A $\delta$-fibres [40, 41]. However, the high expression of $5-\mathrm{HT}_{1 \mathrm{~B}}$ and $5-\mathrm{HT}_{1 \mathrm{D}}$ receptors in whole TG samples observed in $\mathrm{qPCR}$ analysis agrees with previous work and is presently elaborated with their robust expression in neuron somas and $A \delta$-fibres.

The 5- $\mathrm{HT}_{1}$ receptor mRNA expression analysis revealed that $5-\mathrm{HT}_{1 \mathrm{D}}$ receptor mRNA was more prominently expressed than $5-\mathrm{HT}_{1 \mathrm{~B}}$ and $5-\mathrm{HT}_{1 \mathrm{~F}}$, which is comparable to results from previous studies in rats [42] and data from humans, where the $5-\mathrm{HT}_{1 \mathrm{~F}}$ receptor expression is $90 \%$ less than $5-\mathrm{HT}_{1 \mathrm{~B}}$ [43]. Some of the aspects of the current study were addressed using LY-344864 (an earlier $5-\mathrm{HT}_{1 \mathrm{~F}}$ receptor agonist) by Amrutkar and colleagues [42], but there are some important differences. Firstly, the study did not find significant CGRP release inhibition in the TG by LY-344864, and secondly the effect of a $5 \mathrm{HT}_{1 \mathrm{~B}} / 5 \mathrm{HT}_{1 \mathrm{D}}$ receptor antagonist was therefore not evaluated. Similar to our study LY-344864 had inhibitory effect in the dura, and they could not show significant restoration of CGRP release by GR127395. This opens up the possibility that there is a difference in the dural release, plausibly via terminal synapses, when compared the release from the TG.

The light emission data (Fig. 1A) for $5-\mathrm{HT}_{1 \mathrm{~F}}$ receptors did not differ from the negative control. Taken together with the sparse immunohistochemical expression and the relatively low mRNA level, suggests that the concentration of the $5-\mathrm{HT}_{1 \mathrm{~F}}$ receptor is considerably lower than $5-\mathrm{HT}_{1 \mathrm{~B}}$ and $5-\mathrm{HT}_{1 \mathrm{D}}$ receptors in the rat $\mathrm{TG}$ and agrees well with the low expression of $5-\mathrm{HT}_{1 \mathrm{~F}}$ receptors in the A $\delta$-fibres.

While we found co-localization of 5-HT and CGRP in neuron somas, we did not detect any co-localization of 5-HT and CGRP in C-fibres. Similarly, we did not find 5-HT-ir in the axon hillocks of CGRP positive neurons. This may indicate that the observed thin unmyelinated 5-HT positive C-fibres have a different origin as compared to the more classical C-fibres that store CGRP and SP. In the early literature this has been discussed and lesion to the raphe neurons revealed that perivascular microvascular 5-HT fibres may in part originate from these central neurons [44, 45], however this question should in relation to the role of $5-\mathrm{HT}$ in the trigeminal system be addressed in future studies.

The most exciting implication of this study would suggest that 5-HT has a physiological signalling role in the TVS and could be released from neuron cell bodies and fibres. In addition to the fibres of 5-HT that we observed, there could also be other sources of 5-HT. Chan-Palay reported that experimentally labelled 5-HT can be taken up by varicose fibres innervating cerebral blood vessels [46]. Similarly, medullary neurons proximal to large medullary arteries have also been found to contain 5-HT and hypothesized to be chemosensitive [47]. Another aspect is that brain micro vessels were found to contain perivascular 5-HT originating in the raphe nuclei in the brainstem [45]. Importantly our work provides the answer to the long-lasting question, of why are there $5-\mathrm{HT}_{1}$ receptors in the TVS? Showing that 5-HT negatively correlate with the baseline CGRP levels, now we know, that it is most likely not like people decades ago said in relation to discovering triptans, "they are there for us to treat migraine", but that there is a serotonergic signalling system within the TVS, and that 5 -HT receptors have a physiological role.

The results from the 12-month long GLADIATOR study displayed evidence for reduction in headache days and improved MIDAS scores for participants [48]. However, the authors noted a substantial discontinuation of Lasmiditan treatment throughout the study. $42.1 \%$ of the discontinuations were due to "patient request" [49] which comprised e.g. lack of efficacy, dislike of the investigational product or initiation of prohibited medication, among others. It should however be noted that the GLADIATOR study design restricted the patients from driving up to $12 \mathrm{~h}$ after dosing, which likely reduced compliance further. FDA has this now as a note in prescription details for use of Lasmiditan.

Further, a study found almost no correlation between increasing lipophilicity of triptans and their therapeutic gain, while the authors noted an almost significant correlation between increasing lipophilicity and CNS adverse events [50]. This suggests that CNS penetrating antimigraine drugs will have the disadvantage of CNS adverse events (e.g. dizziness). Neither triptans, gepants or monoclonal antibodies (mAbs) can easily cross the BBB or its functional equivalent the blood-spinal cord barrier [51, 52]. However, there are animal studies indicating that triptans may inhibit secondary neurons in the trigeminal nucleus caudalis (TNC) $[21,53,54]$. It remains debated if this occurs in vivo at therapeutic concentrations.

In contrast, the recently introduced drug-class ditans have been shown to cross the BBB in the recommended dose and could thus exert its effect centrally in addition to the periphery. Nevertheless, it is most likely that the inhibitory effect of Lasmiditan on CGRP release occurs in the periphery, and that its lesser effect is to selectively activate the $5-\mathrm{HT}_{1 \mathrm{~F}}$ receptors at secondary neurons inhabiting the TNC within the upper spinal cord. Interestingly, when correlating the plasma concentration needed for effect of Lasmiditan, it aligns with the triptans for the $5-\mathrm{HT}_{1 \mathrm{~B}}$ and $5-\mathrm{HT}_{1 \mathrm{D}}$ receptors (Fig. 8). This in our opinion, combined with the effect of GR127934 (Fig. 10) suggest that part of the anti-migraine effect of Lasmidi$\tan$ is inhibition of CGRP release through "unspecific" activation of $5-\mathrm{HT}_{1 \mathrm{~B}}$ and $5-\mathrm{HT}_{1 \mathrm{D}}$ receptors in the TG. 


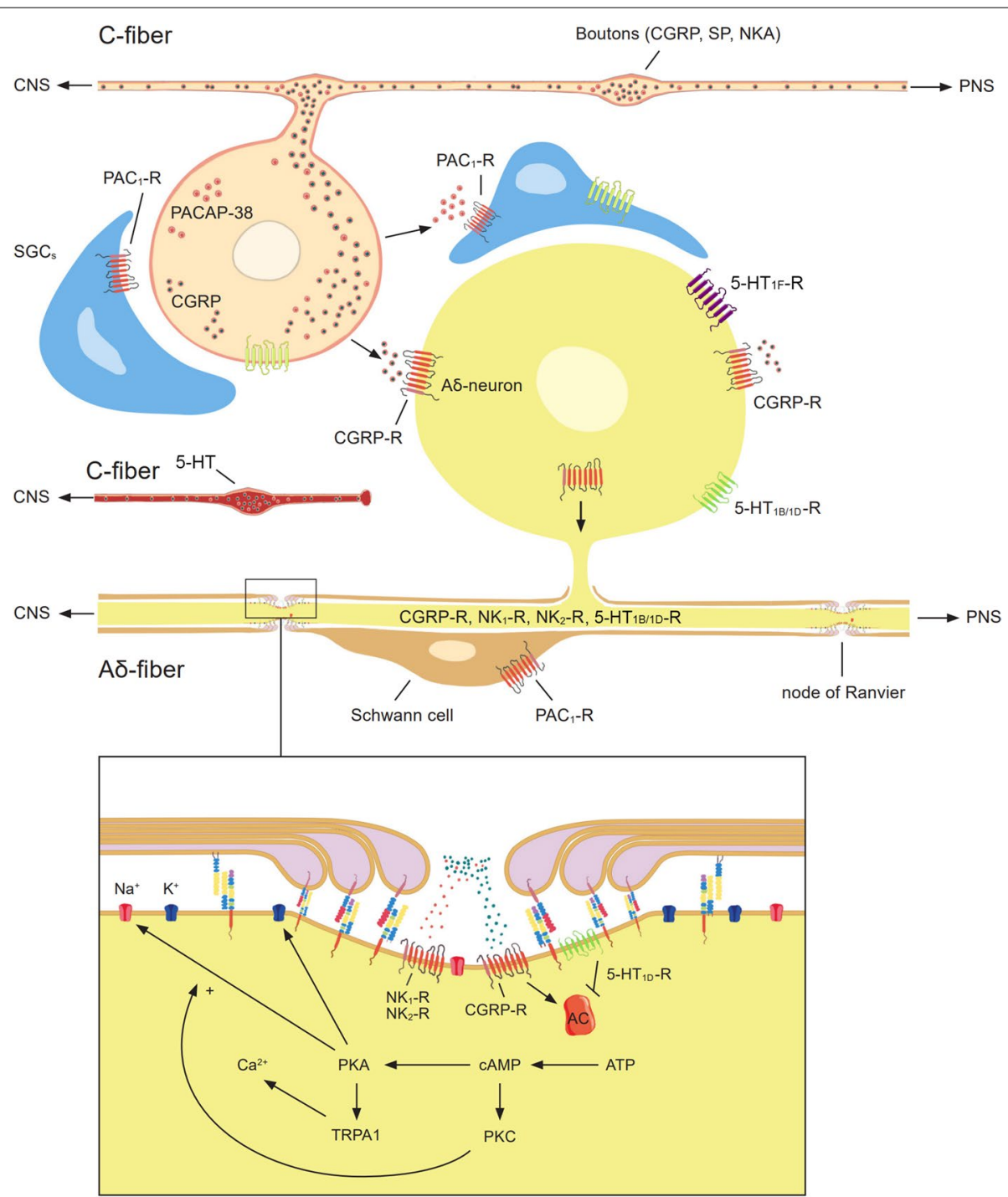

Fig. 13 Simplified overview of immunoreactivity within the rat trigeminal ganglion. The schematic is based on observations made in this, and previous studies [11, 39, 62]. A Expression of 5-HT, CGRP, neurokinin and PACAP-38 signalling elements in trigeminal neurons and glial cells. B Hypothetic CGRP and neurokinin receptor signalling within the nodes of Ranvier of trigeminal A $\delta$-fibres. Abbreviations; neurokinin A (NKA), neurokinin receptor $1\left(\mathrm{NK}_{1}-\mathrm{R}\right)$, neurokinin receptor $2\left(\mathrm{NK}_{2}-\mathrm{R}\right)$, peripheral nervous system (PNS), transient receptor potential ankyrin subtype 1 (TRPA1)

As shown in this study, co-localization of CGRP with $5-\mathrm{HT}_{1 \mathrm{~B} / \mathrm{DD}}$ receptors was not observed in trigeminal C-fibres, but rather in neuron somas. This data implies that the inhibitory action of triptans on CGRP release is not the same in the dura mater and the TG. This has been previously suggested $[55,56]$ and implicates the TG as a treatable target in the processing of migraine pain. Still, there is data showing that sumatriptan can inhibit CGRP release in both dura mater and "soma-rich" TG [39]. Therefore, it could be that the C-fibres just express a modest amount of receptors, which we cannot detect microscopically.
Nevertheless, it raises the question of whether the triptans work the way we currently believe or if neuronal/glial cross talk plays a larger part than previously expected.

Crosstalk between trigeminal neurons and SGCs has been proposed to occur via gap junctions, cytokines, purinergic signalling, glutamate signalling, and others reviewed elsewhere [57]. Purinergic signalling was first proposed to play a role in migraine pain by Burnstock [ 58 , 59], and it has been suggested that increased extracellular ATP activates trigeminal nociceptors via P2X3 receptors [60]. Purinergic signalling from neuron to glial cells could 
be disrupted by activation of the cAMP dependent pathway via CGRP or neurokinin signalling in the trigeminal system. This could occur through intracellular reduction/depletion of ATP mediated by the adenylyl cyclase driven formation of cAMP. Simultaneously, CGRP receptor activation drives the biosynthesis of ATP, ADP and AMP, while reducing internal stores of adenosine, which has been observed in cultured trigeminal neurons and meninges [61]. The same would be true for pituitary adenylate cyclase-activating polypeptide 38 (PACAP-38), although we found no clear pituitary adenylate cyclaseactivating polypeptide receptor $\left(\mathrm{PAC}_{1}-\mathrm{R}\right)$ expression in neurons [62]. Instead the $P C_{1}-R$ was observed mainly in SGCs surrounding neurons, implying a reversed relationship in this signaling system. Furthermore, it is possible that the activation of observed $5-\mathrm{HT}_{1 \mathrm{~B}}$ receptors in SGCs modulates adenylyl cyclase activated by the $P A C_{1}-R$. As $5-\mathrm{HT}_{1 \mathrm{~B}}$ receptor activation is inherently inhibitory, it could, in addition, exert an effect on other pain-related factors (e.g. cytokines) in the crosstalk between neuron and glia. Investigations of novel intercellular signalling mechanism or disruption of an ongoing feedback loop should be addressed in future studies. A simplified overview of our recent observations is presented in Fig. 13.

The current study has some limitations; Firstly, we cannot be sure that the expression data will match that of human subjects as this can vary between species meaning that our study may not necessarily reflect that of a human specimen. However, an earlier study on the expression of $5-\mathrm{HT}_{1 \mathrm{~B} / 1 \mathrm{D}}$ receptors in human trigeminal ganglion shows, in agreement with our present study, that $5-\mathrm{HT}_{1 \mathrm{~B} / 1 \mathrm{D}}$ receptors are co-localized with CGRP and SP in neuron somas but no expression in axons was reported [20]. The receptor expression matches well with the clinical data observed, such as the plasma concentration needed to for clinical effect (Fig. 8). The major limitation is the study being performed in young and healthy animals, and could differ from migraineurs, but could highlight important biological mechanisms. One such mechanisms is the question being raised in the current paper of the potential of direct inhibition of $A \delta$-fibers by $5-\mathrm{HT}_{1 \mathrm{D}}$ receptors. Our data supports such an idea, but studies in human subjects would be needed to support the hypothesis. We believe that revisiting more specific $5-\mathrm{HT}_{1 \mathrm{D}}$ receptor agonists could be a relevant approach.

In conclusion, the $5-\mathrm{HT}_{1 \mathrm{~F}}$ receptor is weakly expressed in the TVS compared with $5-\mathrm{HT}_{1 \mathrm{~B}}$ and $5-\mathrm{HT}_{1 \mathrm{D}}$ receptors. Further, data from our rodent studies combined with analysis of $\mathrm{pEC}_{50}$ and $\mathrm{C}_{\max }$ from the literature, show that parts of the anti-migraine effect of Lasmiditan could occur through activation $5-\mathrm{HT}_{1 \mathrm{~B} / \mathrm{D}}$ receptors. As the $5-\mathrm{HT}_{1 \mathrm{D}}$ receptor does not strong vasocontractile effects, we suggest that a specific
5- $\mathrm{HT}_{1 \mathrm{D}}$ receptor active drug should be revisited. Lastly, we hypothesize that $5-\mathrm{HT}_{1 \mathrm{~B} / 1 \mathrm{D}}$ receptor activation could lead to both the inhibition of CGRP release and the inhibition of the cAMP dependent pathway in trigeminal A $\delta$-fibres.

\section{Abbreviations}

5-HT: 5-Hydroxytryptamine; 5-HT $T_{1 B}$ : 5-Hydroxytryptamine receptor $1 \mathrm{~B} ; 5-H T_{1 D}$ : 5-Hydroxytryptamine receptor 1D;5-HT $: 5$-Hydroxytryptamine receptor $1 \mathrm{~F}$; $B B B$ : Blood-brain barrier; BSA: Bovine serum albumin; CAMP: Cyclic adenosine monophosphate; CASPR: Contactin associated protein 1; CGRP: Calcitonin gene-related peptide; CNS: Central nervous system; $C_{t}$ : Cycle threshold; DMSO: Dimethyl sulfoxide; ELISA: Enzyme-linked immunosorbent assay; GAPDH: Glyceraldehyde-3-phosphate dehydrogenase; IHC: Immunohistochemistry; Ir: Immunoreactivity; MAbs: Monoclonal antibodies; MBP: Myelin basic protein; $N K A$ : Neurokinin $A_{;} ; N K_{1}-R$ : Neurokinin receptor $1 ; N K_{2}-R$ : Neurokinin receptor 2; PACAP-38: Pituitary adenylate cyclase-activating polypeptide 38; $P A C_{1}-R$ : Pituitary adenylate cyclase-activating polypeptide receptor; PBS: Phosphate buffered saline; PBS-T: Phosphate buffered saline with Triton X-100; PNS: Peripheral nervous system; $Q P C R$ : Quantitative polymerase chain reaction; RAMP1: Receptor activity modifying protein 1; SGCS: Satellite glial cells; SP: Substance $P_{i}$ SIF: Synthetic interstitial fluid; TG: Trigeminal ganglion; TNC: Trigeminal nucleus caudalis; TPH:Tryptophan hydroxylase; TRPA1:Transient receptor potential ankyrin subtype 1; TVS:Trigeminovascular system.

\section{Supplementary Information}

The online version contains supplementary material available at https://doi. org/10.1186/s10194-022-01394-z.

Additional file 1: Supplementary Figure 1. Involvement of the $5-\mathrm{HT}_{1 \mathrm{~B}}$ and $5-\mathrm{HT}_{1 \mathrm{D}}$ receptors in the effect of Lasmiditan. Before the addition of 30 $\mu \mathrm{M}$ Lasmiditan, $300 \mathrm{nM}$ of GR127935, a $5 \mathrm{HT}_{1 \mathrm{~B}} / 5 \mathrm{HT}_{1 \mathrm{D}}$ blocker was added to the TG which subsequently stimulated with $60 \mathrm{mM} \mathrm{KCl}\left(\mathrm{K}^{+}\right)$. Data are shown as mean \pm SEM with * $p>0.05$, from the paired Student's T-test being depicted in the graph.

Additional file 2: Supplementary Figure 2. Involvement of the $5-\mathrm{HT}_{1 \mathrm{D}}$ receptors in the effect of Lasmiditan. Before the addition of 30 $\mu \mathrm{M}$ Lasmiditan, $1.25 \mu \mathrm{M}$ of BRL15572, a $5 \mathrm{HT}_{1 \mathrm{D}}$ receptor antagonist was added to the dura $(n=5)$ which subsequently stimulated with $60 \mathrm{mM}$ $\mathrm{KCl}\left(\mathrm{K}^{+}\right)$. Similarly, before the addition of $60 \mathrm{mM} \mathrm{KCl}\left(\mathrm{K}^{+}\right) 1.25 \mu \mathrm{M}(n=5)$ of BRL15572, was added to the TGs which subsequently stimulated with $60 \mathrm{mM} \mathrm{KCl}\left(\mathrm{K}^{+}\right)$. BRL15572 significantly inhibited CGRP release further in the dura $(P=0.0456)$ with a tendency observed in the TG at the same concentration. Data are shown as mean \pm SEM with * $p>0.05$, from the paired Student's T-test being depicted in the graph.

Additional file 3: Supplementary Table 1. Data points used for correlation in Fig. 8.

\section{Acknowledgements}

Not applicable.

\section{Authors' contributions \\ JE, LE and KAH designed the study. JE, AM, IMC, PVR and KAH performed the experiments. LE and KAH provided tools and reagents. JE, LE and KAH wrote the manuscript. AM, IMC, PVR, MS and KW made further critical manuscript revisions. All authors read and approved the final manuscript.}

Funding

KAH and PVR were supported by a Lundbeck foundation Fellowship (R3452020-1977) and a grant from the International Headache Society. The other authors received no specific funding for this work.

\section{Availability of data and materials}

The datasets generated during and/or analysed during the current study are available from the corresponding author on reasonable request. 


\section{Declarations}

\section{Ethics approval and consent to participate}

The experimental procedures for the IHC and qPCR in Sweden were approved by the Lund University Animal Ethics Committee (M43-07). The CGRP release experiments performed in Denmark were approved by The Danish Animal Experimentation Inspectorate. All experiments were performed in accordance with the European Community Council Directive on 'The Protection of Animals Used for Scientific Purposes' (2010/63/EU).

\section{Consent for publication}

Not applicable.

\section{Competing interests}

The authors declare that they have no competing interests.

\section{Author details}

'Department of Clinical Experimental Research, Glostrup Research Institute, Rigshospitalet Glostrup, 2600 Glostrup, Denmark. ²Department of Drug Design and Pharmacology, Faculty of Health and Medical Sciences, University of Copenhagen, Copenhagen, Denmark. ${ }^{3}$ Division of Experimental Vascular Research, Department of Clinical Sciences, Lund University Hospital, Lund, Sweden. ${ }^{4}$ Department of Biology, University of Copenhagen, Copenhagen, Denmark.

Received: 7 December 2021 Accepted: 21 January 2022

Published online: 17 February 2022

\section{References}

1. Ashina M, Hansen JM, á Dunga BO, Olesen J. (2017) Human models of migraine - short-term pain for long-term gain. Nat Rev Neurol. 13(12):713-724

2. Goadsby PJ (2009) The vascular theory of migraine-a great story wrecked by the facts. Brain 132(1):6-7

3. Goadsby PJ, Holland PR, Martins-Oliveira M, Hoffmann J, Schankin C, Akerman S (2017) Pathophysiology of Migraine: A Disorder of Sensory Processing. Physiol Rev. 97(2):553-622

4. Schulte LH, Menz MM, Haaker J, May A (2020) The migraineur's brain networks: Continuous resting state fMRI over 30 days. Cephalalgia. 40(14):1614-1621

5. Schulte LH, Mehnert J, May A (2020) Longitudinal Neuroimaging over 30 Days: Temporal Characteristics of Migraine. Ann Neurol. 87(4):646-651

6. Edvinsson J, Viganò A, Alekseeva A, Alieva E, Arruda R, De Luca C et al (2020) The fifth cranial nerve in headaches. J Headache Pain. 21:1-17

7. Ferrari MD, Roon Kl, Lipton RB, Goadsby PJ (2001) Oral triptans (serotonin 5-HT1B/1D agonists) in acute migraine treatment: a meta-analysis of 53 trials. Lancet. 358(9294):1668-1675

8. Tepper SJ, Rapoport AM, Sheftell FD (2002) Mechanisms of Action of the 5-HT1B/1D Receptor Agonists. Arch Neurol. 59(7):1084-1088

9. Saxena PR, Ferrari MD (1989) 5-HT(1)-like receptor agonists and the pathophysiology of migraine. Trends Pharmacol Sci. 10(5):200-204

10. Goadsby PJ, Edvinsson L (1993) The trigeminovascular system and migraine: studies characterizing cerebrovascular and neuropeptide changes seen in humans and cats. Ann Neurol 33(1):48-56

11. Edvinsson JC, Reducha P, Sheykhzade M, Warfvinge K, Haanes KA, Edvinsson $L$ (2021) Neurokinins and their receptors in the rat trigeminal system: Differential localization and release with implications for migraine pain. Mol Pain 00

12. Durham PL, Russo AF (1999) Regulation of calcitonin gene-related peptide secretion by a serotonergic antimigraine drug. J Neurosci 19(9):3423-3429

13. Goadsby PJ (1998) Serotonin 5-HT1B/1D Receptor Agonists in Migraine CNS Drugs. 10(4):271-286

14. Goadsby PJ, Lipton RB, Ferrari MD (2002) Migraine-current understanding and treatment. N Engl J Med 346(4):257-270

15. Nilsson T, Longmore J, Shaw D, Olesen IJ, Edvinsson L (1999) Contractile 5-HT1B receptors in human cerebral arteries: pharmacological characterization and localization with immunocytochemistry. Br J Pharmacol. 128(6):1133-1140

16. Razzaque Z, Heald MA, Pickard JD, Maskell L, Beer MS, Hill RG et al (1999) Vasoconstriction in human isolated middle meningeal arteries: determining the contribution of 5-HT1B- and 5-HT1F-receptor activation. Br J Clin Pharmacol. 47(1):75-82

17. Edvinsson L, Uddman E, Wackenfors A, Davenport A, Longmore J, Malmsjö M (2005) Triptan-induced contractile (5-HT1B receptor) responses in human cerebral and coronary arteries: relationship to clinical effect. Clin Sci 109(3):335-342

18. Longmore J, Maguire JJ, MacLeod A, Street L, Schofield WN, Hill RG (2000) Comparison of the vasoconstrictor effects of the selective 5-HT1Dreceptor agonist L-775,606 with the mixed 5-HT1B/1D-receptor agonist sumatriptan and 5-HT in human isolated coronary artery. Br J Clin Pharmacol 49(2):126-131

19. Rebeck GW, Maynard KI, Hyman BT, Moskowitz MA (1994) Selective 5-HT1D alpha serotonin receptor gene expression in trigeminal ganglia: implications for antimigraine drug development. Proc Natl Acad Sci 91(9):3666-3669

20. Hou M, Kanje M, Longmore J, Tajti J, Uddman R, Edvinsson L (2001) 5-HT1B and 5-HT1D receptors in the human trigeminal ganglion: colocalization with calcitonin gene-related peptide, substance $P$ and nitric oxide synthase. Brain Res 909(1-2, 112):-20

21. Goadsby PJ, Edvinsson L (1994) Joint 1994 Wolff Award Presentation. Peripheral and central trigeminovascular activation in cat is blocked by the serotonin (5HT)-1D receptor agonist 311C90. Headache. 34(7):394-399

22. Clemow DB, Johnson KW, Hochstetler HM, Ossipov MH, Hake AM, Blumenfeld AM (2020) Lasmiditan mechanism of action-review of a selective 5-HT 1F agonist. J Headache Pain. 21(1):1-13

23. Rubio-Beltrán E, Labastida-Ramírez A, Haanes KA, van den Bogaerdt $A$ Bogers AJ, Zanelli E et al (2019) Characterization of binding, functiona activity, and contractile responses of the selective 5-HT1F receptor agonist lasmiditan. Br J Pharmacol 176(24):4681-4695

24. Labastida-Ramírez A, Rubio-Beltrán E, Haanes KA, Chan KY, Garrelds IM, Johnson KW et al (2020) Lasmiditan inhibits calcitonin generelated peptide release in the rodent trigeminovascular system. Pain. 161(5):1092

25. Shepheard S, Edvinsson L, Cumberbatch M, Williamson D, Mason G, Webb J et al (1999) Possible antimigraine mechanisms of action of the 5HT1F receptor agonist LY334370. Cephalalgia. 19(10):851-858

26. Goadsby P, Classey J (2003) Evidence for serotonin (5-HT) 1B, 5-HT1D and 5-HT1F receptor inhibitory effects on trigeminal neurons with craniovascular input. Neuroscience 122(2):491-498

27. Gomez-Mancilla B, Cutler N, Leibowitz M, Spierings E, Klapper J, Diamond S et al (2001) Safety and Efficacy of PNU-142633, a Selective 5-HT1D Agonist, in Patients with Acute Migraine. Cephalalgia 21(7):727-732

28. Ferrari MD. (2001) Re Gomez-Mancilla et al. Safety and efficacy of PNU142633, a selective 5-HT(1D) agonist, in patients with acute migraine. Cephalalgia:;21(7):711.

29. Mathiau P, Bakalara N, Aubineau P (1994) Tryptophan hydroxylase can be present in mast cells and nerve fibers of the rat dura mater but only mast cells contain serotonin. Neurosci Lett 182(2):133-137

30. Clark MS, Russo AF (1998) Measurement of tryptophan hydroxylase mRNA levels by competitive RT-PCR. Brain Res Protocol 2(4):273-285

31. Schneider CA, Rasband WS, Eliceiri KW. NIH Image to ImageJ: 25 years of image analysis. Nat Methods. 2012;9:671-5.

32. Haanes KA, Labastida-Ramirez A, Blixt FW, Rubio-Beltran E, Dirven CM, Danser AH et al (2019) Exploration of purinergic receptors as potential anti-migraine targets using established pre-clinical migraine models. Cephalalgia. 39(11):1421-1434

33. Hansen-Schwartz J, Hoel NL, Zhou M, Xu C-B, Svendgaard N-A, Edvinsson $L$ (2003) Subarachnoid Hemorrhage Enhances Endothelin Receptor Expression and Function in Rat Cerebral Arteries. Neurosurgery. 52(5):1188-1195

34. Selkirk J, Scott C, Ho M, Burton M, Watson J, Gaster L et al (1998) SB224289-a novel selective (human) 5-HT1B receptor antagonist with negative intrinsic activity. Br J Pharmacol 125(1):202-208 
35. Levy D (2009) Migraine pain, meningeal inflammation, and mast cells. Curr Pain Headache Rep 13(3):237-240

36. Chouchkov C, Lazarov N, Davidoff M (1988) Serotonin-like immunoreactivity in the cat trigeminal ganglion. Histochemistry 88(3):637-639

37. Keller JT, Marfurt CF (1991) Peptidergic and serotoninergic innervation of the rat dura mater. J Comp Neurol 309(4):515-534

38. Frederiksen SD, Warfvinge K, Ohlsson L, Edvinsson L (2018) Expression of pituitary adenylate cyclase-activating peptide, calcitonin gene-related peptide and headache targets in the trigeminal ganglia of rats and humans. Neuroscience 393:319-332

39. Edvinsson JC, Warfvinge K, Krause DN, Blixt FW, Sheykhzade M, Edvinsson L et al (2019) C-fibers may modulate adjacent A $\delta$-fibers through axon-axon CGRP signaling at nodes of Ranvier in the trigeminal system. J Headache Pain 20(1):1-10

40. Edvinsson L, Haanes KA (2021) Identifying New Antimigraine Targets: Lessons from Molecular Biology. Trends Pharmacol Sci. 42(4):217-225

41. Haanes KA, Edvinsson L (2019) Pathophysiological Mechanisms in Migraine and the Identification of New Therapeutic Targets. CNS Drugs. 33(6):525-537

42. Amrutkar DV, Ploug KB, Hay-Schmidt A, Porreca F, Olesen J, Jansen-Olesen I (2012) mRNA expression of 5-hydroxytryptamine 1B, 1D, and 1F receptors and their role in controlling the release of calcitonin gene-related peptide in the rat trigeminovascular system. Pain 153(4):830-838

43. Flegel C, Schobel N, Altmuller J, Becker C, Tannapfel A, Hatt H et al (2015) RNA-Seq Analysis of Human Trigeminal and Dorsal Root Ganglia with a Focus on Chemoreceptors. PLoS One 10(6):e0128951

44. Reinhard JF, Liebmann JE, Schlosberg AJ, Moskowitz MA (1979) Serotonin neurons project to small blood vessels in the brain. Science 206(4414):85-87

45. Edvinsson L, Degueurce A, Duverger D, Mackenzie ET, Scatton B (1983) Central serotonergic nerves project to the pial vessels of the brain. Nature. 306(5938):55-57

46. Chan-Palay V (1976) Serotonin axons in the supra-and subependymal plexuses and in the leptomeninges; their roles in local alterations of cerebrospinal fluid and vasomotor activity. Brain Res 102(1):103-130

47. Bradley SR, Pieribone VA, Wang W, Severson CA, Jacobs RA, Richerson GB (2002) Chemosensitive serotonergic neurons are closely associated with large medullary arteries. Nature Neurosci 5(5):401-402

48. Lipton RB, Lombard L, Ruff DD, Krege JH, Loo LS, Buchanan A et al (2020) Trajectory of migraine-related disability following long-term treatment with lasmiditan: results of the GLADIATOR study. J Headache Pain 21(1):20

49. Brandes JL, Klise S, Krege JH, Case M, Khanna R, Vasudeva R et al (2019) Interim results of a prospective, randomized, open-label, phase 3 study of the long-term safety and efficacy of lasmiditan for acute treatment of migraine (the GLADIATOR study). Cephalalgia. 39(11):1343-1357

50. Pascual J, Muñoz P (2005) Correlation between lipophilicity and triptan outcomes. Headache. 45(1):3-6

51. Lundblad C, Haanes KA, Grände G, Edvinsson L (2015) Experimental inflammation following dural application of complete Freund's adjuvant or inflammatory soup does not alter brain and trigeminal microvascular passage. J Headache Pain 16(1):91

52. Noseda R, Schain AJ, Melo-Carrillo A, Tien J, Stratton J, Mai F et al (2020) Fluorescently-labeled fremanezumab is distributed to sensory and autonomic ganglia and the dura but not to the brain of rats with uncompromised blood brain barrier. Cephalalgia 40(3):229-240

53. Hoskin KL, Kaube H, Goadsby PJ (1996) Central activation of the trigeminovascular pathway in the cat is inhibited by dihydroergotamine: a c-Fos and electrophysiological study. Brain 119(1):249-256

54. Hoskin KL, Lambert GA, Donaldson C, Zagami AS (2004) The 5-hydroxytryptamine1B/1D/1F receptor agonists eletriptan and naratriptan inhibit trigeminovascular input to the nucleus tractus solitarius in the cat. Brain Res 998(1):91-99

55. Messlinger K (2018) The big CGRP flood-sources, sinks and signalling sites in the trigeminovascular system. J Headache Pain 19(1):1-7

56. Messlinger K, Russo AF (2019) Current understanding of trigeminal ganglion structure and function in headache. Cephalalgia. 39(13):1661-1674
57. Messlinger K, Balcziak LK, Russo AF (2020) Cross-talk signaling in the trigeminal ganglion: role of neuropeptides and other mediators. J Neural Transm 127(4):431-444

58. Burnstock $G$ (1981) Pathophysiology of migraine: a new hypothesis Lancet. 317(8235):1397-1399

59. Burnstock G, Ralevic V (2014) Purinergic signaling and blood vessels in health and disease. Pharmacol Rev 66(1):102-192

60. Giniatullin R, Nistri A, Fabbretti E (2008) Molecular mechanisms of sensitization of pain-transducing $P 2 X 3$ receptors by the migraine mediators CGRP and NGF. Mol Neurobiol 37(1):83-90

61. Yegutkin GG, Guerrero-Toro C, Kilinc E, Koroleva K, Ishchenko Y, Abushik P et al (2016) Nucleotide homeostasis and purinergic nociceptive signaling in rat meninges in migraine-like conditions. Purinergic Signal 12(3):561-574

62. Edvinsson JCA, Grell A-S, Warfvinge K, Sheykhzade M, Edvinsson L, Haanes KA (2020) Differences in pituitary adenylate cyclase-activating peptide and calcitonin gene-related peptide release in the trigeminovascular system. Cephalalgia 40(12):1296-1309

\section{Publisher's Note}

Springer Nature remains neutral with regard to jurisdictional claims in published maps and institutional affiliations.

Ready to submit your research? Choose BMC and benefit from:

- fast, convenient online submission

- thorough peer review by experienced researchers in your field

- rapid publication on acceptance

- support for research data, including large and complex data types

- gold Open Access which fosters wider collaboration and increased citations

- maximum visibility for your research: over 100M website views per year

At BMC, research is always in progress.

Learn more biomedcentral.com/submissions 